\title{
Quantifying the effects of land use and climate on Holocene vegetation in Europe
}

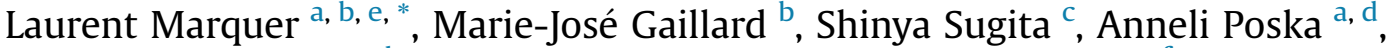 \\ Anna-Kari Trondman ${ }^{b}$, Florence Mazier ${ }^{\mathrm{e}}$, Anne Birgitte Nielsen ${ }^{\mathrm{a}}$, , Ralph M. Fyfe ${ }^{\mathrm{g}}$, \\ Anna Maria Jönsson a , Benjamin Smith ${ }^{\text {a }}$, Jed O. Kaplan ${ }^{\text {h }}$, Teija Alenius ${ }^{\mathrm{i}, \mathrm{j}}$, \\ H. John B. Birks ${ }^{k, 1}$, Anne E. Bjune ${ }^{k, m}$, Jörg Christiansen ${ }^{n}$, John Dodson ${ }^{\circ, p}$, \\ Kevin J. Edwards q, r, Thomas Giesecke ${ }^{\mathrm{n}}$, Ulrike Herzschuh ${ }^{\text {s }}$, Mihkel Kangur ${ }^{\mathrm{c}}$, Tiiu Koff ${ }^{\mathrm{c}}$, \\ Małgorzata Latałowa ${ }^{t}$, Jutta Lechterbeck ${ }^{u}$, Jörgen Olofsson ${ }^{a}$, Heikki Seppä v
}

a Department of Physical Geography and Ecosystem Science, Lund University, Sweden

${ }^{\mathrm{b}}$ Department of Biology and Environmental Science, Linnaeus University, Sweden

${ }^{\mathrm{c}}$ Institute of Ecology, Tallinn University, Estonia

${ }^{\mathrm{d}}$ Institute of Geology, Tallinn University of Technology, Estonia

e GEODE, UMR-CNRS 5602, Université Toulouse Jean Jaurès, France

${ }^{\mathrm{f}}$ Department of Geology, Lund University, Sweden

${ }^{g}$ School of Geography, Earth and Environmental Sciences, University of Plymouth, United Kingdom

${ }^{\mathrm{h}}$ ARVE, Ecole Polytechnique Fédérale de Lausanne, Switzerland

${ }^{i}$ Department of Philosophy, History, Culture and Art Studies, University of Helsinki, Finland

j Department of Archaeology, University of Turku, Finland

${ }^{\mathrm{k}}$ Department of Biology and Bjerknes Centre for Climate Research, University of Bergen, Norway

${ }^{1}$ Environmental Change Research Centre, University College London, United Kingdom

${ }^{\mathrm{m}}$ Uni Research Climate, Bergen, Norway

n Department of Palynology and Climate Dynamics, Albrecht-von-Haller-Institute for Plant Sciences, University of Göttingen, Germany

${ }^{\circ}$ School of Earth and Environmental Sciences, University of Wollongong, Wollongong, Australia

p State Key Laboratory of Loess and Quaternary Geology, Institute of Earth Environment, Chinese Academy of Sciences, Xi'an, Shaanxi, China

${ }^{\mathrm{q}}$ Departments of Geography \& Environment and Archaeology, School of Geosciences, University of Aberdeen, United Kingdom

${ }^{\mathrm{r}}$ Clare Hall, University of Cambridge, United Kingdom

${ }^{s}$ Alfred-Wegener-Institut Potsdam and Institut für Geowissenschaften, Universität Potsdam, Germany

${ }^{\mathrm{t}}$ Laboratory of Palaeoecology and Archaebotany, Department of Plant Ecology, University of Gdańsk, Poland

u Arkeologisk Museum, Universitetet i Stavanger, Stavanger, Norway

${ }^{v}$ Department of Geosciences and Geography, University of Helsinki, Finland

\section{A R T I C L E I N F O}

\section{Article history:}

Received 14 February 2017

Received in revised form

1 July 2017

Accepted 2 July 2017

\section{Keywords:}

Climate

Holocene

\begin{abstract}
A B S T R A C T
Early agriculture can be detected in palaeovegetation records, but quantification of the relative importance of climate and land use in influencing regional vegetation composition since the onset of agriculture is a topic that is rarely addressed. We present a novel approach that combines pollen-based REVEALS estimates of plant cover with climate, anthropogenic land-cover and dynamic vegetation modelling results. This is used to quantify the relative impacts of land use and climate on Holocene vegetation at a sub-continental scale, i.e. northern and western Europe north of the Alps. We use redundancy analysis and variation partitioning to quantify the percentage of variation in vegetation composition explained by the climate and land-use variables, and Monte Carlo permutation tests to assess the statistical significance of each variable. We further use a similarity index to combine pollen-
\end{abstract}

\footnotetext{
* Corresponding author. Department of Physical Geography and Ecosystem Science, Lund University, Sweden.

E-mail addresses: laurent.marquer.es@gmail.com (L. Marquer), marie-jose.gaillard-lemdahl@lnu.se (M.-J. Gaillard), sugita@tlu.ee (S. Sugita), anneli.poska@ttu.ee

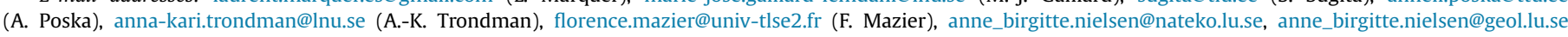

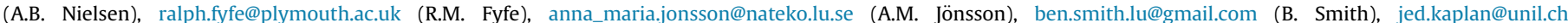

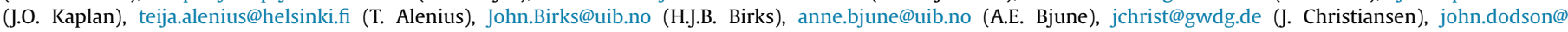

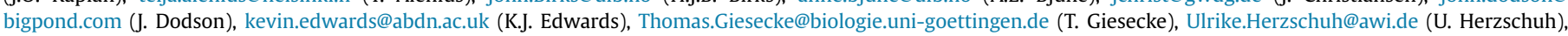

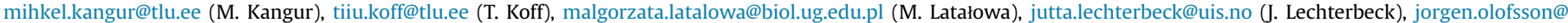
nateko.lu.se (J. Olofsson), heikki.seppa@helsinki.fi (H. Seppä).
} 
Human impact

Land use

LPJ-GUESS

Europe

Pollen

REVEALS

Vegetation composition based REVEALS estimates with climate-driven dynamic vegetation modelling results. The overall results indicate that climate is the major driver of vegetation when the Holocene is considered as a whole and at the sub-continental scale, although land use is important regionally. Four critical phases of land-use effects on vegetation are identified. The first phase (from 7000 to $6500 \mathrm{BP}$ ) corresponds to the early impacts on vegetation of farming and Neolithic forest clearance and to the dominance of climate as a driver of vegetation change. During the second phase (from 4500 to 4000 BP), land use becomes a major control of vegetation. Climate is still the principal driver, although its influence decreases gradually. The third phase (from 2000 to $1500 \mathrm{BP}$ ) is characterised by the continued role of climate on vegetation as a consequence of late-Holocene climate shifts and specific climate events that influence vegetation as well as land use. The last phase (from 500 to $350 \mathrm{BP}$ ) shows an acceleration of vegetation changes, in particular during the last century, caused by new farming practices and forestry in response to population growth and industrialization. This is a unique signature of anthropogenic impact within the Holocene but European vegetation remains climatically sensitive and thus may continue to respond to ongoing climate change.

(c) 2017 Elsevier Ltd. All rights reserved.

\section{Introduction}

Past vegetation cover is a result of many environmental factors, of which soils, climate and human impacts are assumed to have been the most important during the Holocene, though their relative importance for various regions and time periods is a matter of debate. Strong palaeoecological evidence exists for anthropogenic forcing of vegetation in Europe since the mid-Holocene (e.g. Behre, 1988), and knowledge of how natural and human agents interacted to influence vegetation changes in the past and present is of major interest for conservation strategies and for improving projections of vegetation responses to climate change (Willis and Birks, 2006; Jönsson et al., 2015). Analysis of pollen records offers a potential approach to quantifying the relative importance of human- and climate-induced changes in Holocene vegetation but is hampered particularly by the differential production and dispersal of pollen. Models of pollen-vegetation relationships, and model-based reconstructions of vegetation composition and abundance at local and regional scales using fossil pollen data, have developed since the 1980s (e.g. Prentice and Parsons, 1983; Sugita, 1994, 2007a, 2007b; Gaillard et al., 2008). Within the framework of the LANDCLIM project (Gaillard et al., 2010), pollen-based quantitative estimates of Holocene vegetation composition using the REVEALS model (Sugita, 2007a) have been produced for Europe north of the Alps (Nielsen et al., 2012; Fyfe et al., 2013; Marquer et al., 2014; Trondman et al., 2015, 2016).

Major differences over space (at a sub-continental scale) and time (through the Holocene) exist in Europe between REVEALSbased vegetation (RV) estimates and untransformed pollen percentages (PP) that are commonly used for the interpretation of pollen diagrams (e.g. Gaillard et al., 2010). Marquer et al. (2014) found that the timing of major Holocene shifts and indices of vegetation change (rates of compositional change, turnover, RV evenness) are different between RV and PP, and that plant composition and abundance as indicated by RV were affected to a larger extent by Neolithic deforestation and agricultural activities than previously interpreted from PP. Four trajectories of change were identified from RV across northern Europe. In northern Germany and Poland, the onset of human impact on vegetation composition was found to have started from ca. $6700 \mathrm{cal} \mathrm{yr} \mathrm{BP.} \mathrm{An}$ early human impact in this region has also been proposed by Nielsen et al. (2012), although it is widely assumed that climate was the main driver of changes in vegetation composition in the midHolocene. Marquer et al. (2014) found rapid compositional change, a large decrease in turnover, and stabilisation or decrease in RV evenness in most of northern Europe after 5200 cal yr BP, which was ascribed to land-use changes. This corresponds temporally to regional agricultural intensification and population growth in Europe as described by Shennan et al. (2013). Davis et al. (2015) argue that the modern patterns of European vegetation started $5000-4000$ years ago and were largely completed by 2000 years ago in lowland Europe. Davis et al. (2015) and Fyfe et al. (2015) both recognised an important shift in European land-cover around 2200 years ago. Marquer et al. (2014) showed that over the last 2000 years rates of change accelerated again and turnover reached its lowest values for the entire Holocene due to an increase in arable land-cover in northern Europe. Whilst Marquer et al. (2014) assume that these changes were primarily anthropogenically-driven, climate may well have remained an important control of vegetation composition, and this hypothesis remains to be tested at the European scale.

For Estonia over the last 5000 years, Reitalu et al. (2013) used a set of statistical analyses (redundancy analysis, variation partitioning, linear mixed-effects models) to assess the extent of climate influence $\left(\delta^{18} \mathrm{O}\right.$ records and simulated temperature) and human impact (frequencies of pollen indicators of human-induced vegetation and fire indices) on forest composition as estimated by the REVEALS model. Their results suggest that human impact was the strongest driver of forest compositional change between 4000 and 2000 years ago, but that both climate and humans have had significant effects on the changes. The study highlighted the potential of statistical approaches to quantify human and climate influences on RV vegetation estimates. Kuosmanen et al. (2016a, 2016b) applied similar approaches in Russia and Fennoscandia, using vegetation changes based on fossil pollen (no REVEALS estimates) and conifer stomata, forest fires (charcoal data), climate variables $\left(\delta^{18} \mathrm{O}\right.$ records and simulated temperature) and data for human population size (derived from archaeologically-derived radiocarbon estimates). The results indicate that climate was the main driver of Holocene forest composition at a regional scale. These two studies support the notion that climate may have remained an important driver of vegetation in northern Europe until recently.

The present study aims to quantify the respective roles played by land use and climate in Holocene vegetation from regional to sub-continental scales for northern and western Europe north of the Alps. We develop here a novel approach to combine pollenbased REVEALS estimates of plant cover with climate, dynamic vegetation and anthropogenic land-cover (anthropogenic deforestation) modelling. This approach seeks to assess whether climate was and still is a major control of change in the development of Holocene vegetation. 


\section{Materials and methods}

\subsection{Study area and selection of pollen records}

The study area is the same as that targeted by Marquer et al. (2014) (Fig. 1) and includes a large part of northern and Central Europe, i.e. Ireland, Great Britain and a latitudinal transect from the Alps in the south to northernmost Norway. It is characterised by a long history of agricultural development and major biogeographic and climatic gradients (Berglund et al., 1996). It is also appropriate for the application of the REVEALS model because the necessary pollen-productivity estimates are available for the major pollen taxa in this region (Broström et al., 2008; Mazier et al., 2012).

The 151 pollen records used in this study were selected from the European Pollen Database (Fyfe et al., 2009; Giesecke et al., 2014a), the Alpine Palynological Data-Base (University of Bern, Switzerland), or were provided directly by individual data contributors (see Appendix A). The selected pollen records were grouped into $361^{\circ} \times 1^{\circ}$ grid-cells (see Appendices A and B for details) which were classified into four latitudinal regions between 7 and $30^{\circ}$ E (Fig. 1): Region A ( $\left.46-49^{\circ} \mathrm{N}\right)$, Region B $\left(51-55^{\circ} \mathrm{N}\right)$, Region $\mathrm{C}\left(55-64^{\circ} \mathrm{N}\right)$ and Region D $\left(68-71^{\circ} \mathrm{N}\right)$. A fifth area, Region E, corresponds to the westernmost grid-cells $\left(52-58^{\circ} \mathrm{N}\right.$ and $\left.10^{\circ} \mathrm{W}-1^{\circ} \mathrm{E}\right)$. The five sub-regions represent a compromise between a sufficient number of grid cells in each sub-region to run the statistical analyses and appropriate latitudinal gradients for climate, land-use and vegetation data. The grid system (grid-cell size and geographical position) is the one used by the LANDCLIM project (Gaillard et al., 2010) and for all REVEALS reconstructions within the project (e.g. Trondman et al., 2015).

\subsection{Approach}

The dataset of past vegetation for the Holocene comprises pollen-based quantitative reconstructions of vegetation abundance, i.e. continuous REVEALS estimates of the cover of 25 plant taxa (RV), for consecutive time windows. We use the grid-based RV data (see above and Fig. 1) - i.e. means of RV from multiple sites distributed within the $1^{\circ} \times 1^{\circ}$ area of each grid cell (Trondman et al., 2015) rather than the site-specific RV data deployed in Marquer et al. (2014). Our aim was to enlarge the dataset of past vegetation to include grid cells that do not include only large lakes ( $\geq 50 \mathrm{ha}$ ) in order to test the influence of climate and land use on vegetation development in a much larger number of grid cells than was available from the study of Marquer et al. (2014). Although pollen records from large sites are considered preferable when using the REVEALS model for reconstructions (Sugita, 2007a), it has been shown both theoretically (Sugita, 2007a) and empirically (Trondman et al., 2016) that pollen records from multiple small sites (lakes or bogs) are also suitable for reliable REVEALS reconstructions.

To test and quantify the effects of climate and land use on Holocene vegetation composition, datasets of climate and land-use estimates (explanatory variables) that are independent of the datasets of vegetation (response variables) are needed. Explanatory datasets should be from the same locations as the response variables. As there are no empirical data of climate and land use matching these requirements, we are restricted to using simulation-based estimates. Therefore, temperature and precipitation data from the Earth System Model (ESM, Schurgers et al., 2006; Mikolajewicz et al., 2007) are used as the climate variable, and the human deforestation data from the 'Krumhardt Kaplan

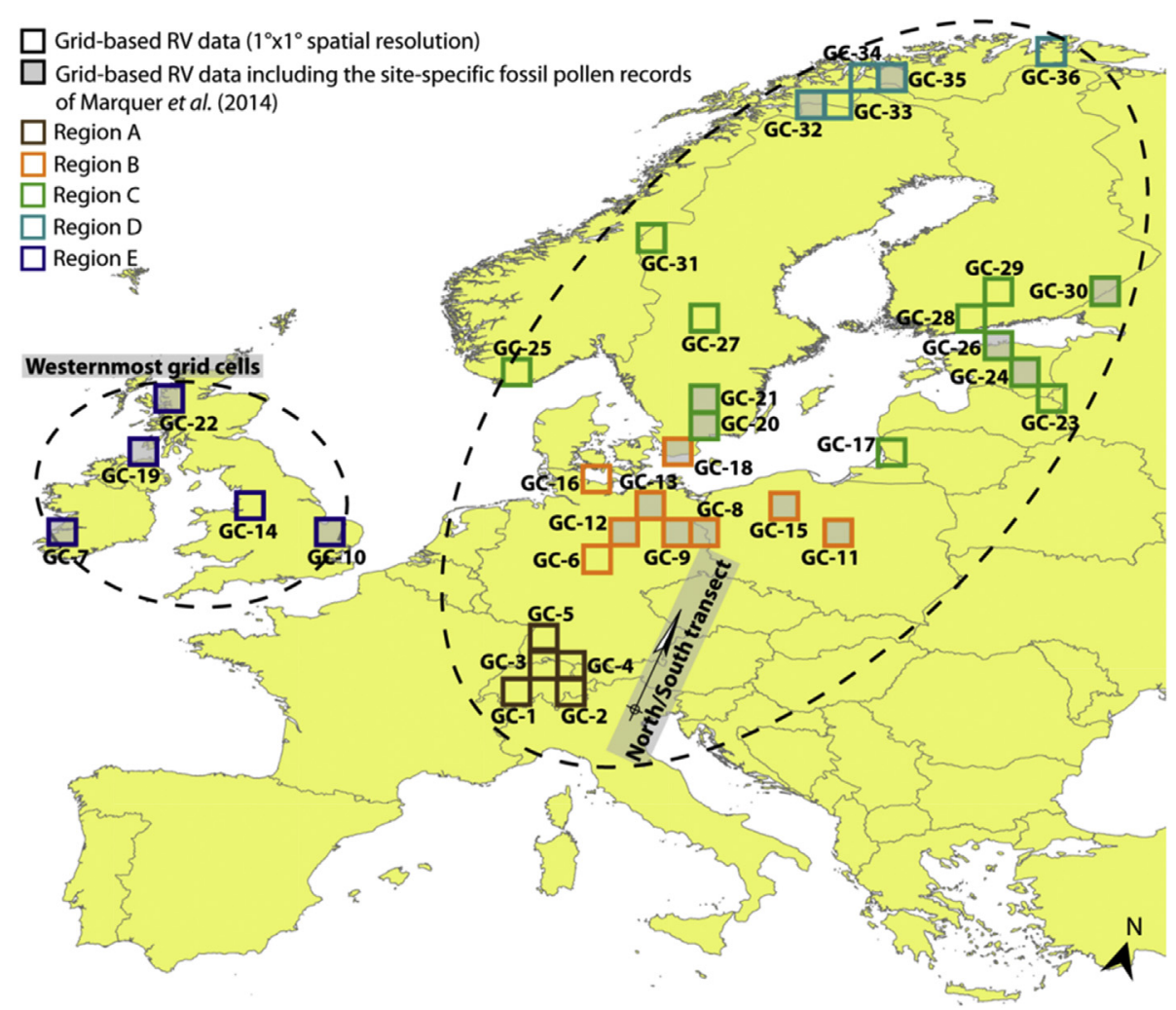

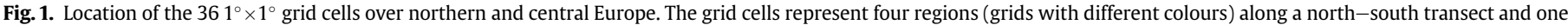

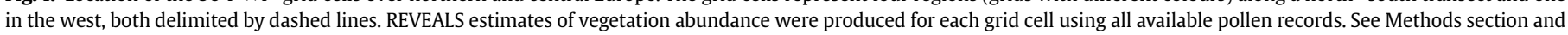
Appendices A and B for detailed information. (For interpretation of the references to colour in this figure legend, the reader is referred to the web version of this article.) 
version 2010' (KK10) scenario (Kaplan et al., 2009) as the land-use variable. We used redundancy analysis (RDA) and variation partitioning (VP) to quantify the percentage of variation in RV explained by the climate and land-use variables (Fig. 2). Indices of vegetation change (Fig. 2 and see section 2.5.2) based on RV and potential natural vegetation simulated based on climate forcing by the dynamic vegetation model LPJ-GUESS (Smith et al., 2001) have also been used to assess the possible land-use effect on vegetation. Indices based on RV (both climate- and human-induced) and climate-induced potential natural vegetation (influenced by natural factors such as climate, soils and biotic interactions) are compared by applying a similarity index $(S)$ in order to identify periods when land use might have influenced vegetation (i.e. periods when low similarity indicate the impact of human activities on vegetation).

\subsection{Pollen-based REVEALS estimates of vegetation abundance}

The REVEALS model (Sugita, 2007a) was applied to obtain pollen-based estimates of regional abundances (in percentage cover) of 25 plant taxa (pollen-type equivalent groups), and associated standard errors, for each grid-cell using pollen data from all sites (small/large, lakes/bogs/mires) (see Appendix B for more details on the model and its application). The REVEALS model corrects for the non-linear nature of pollen-vegetation relationships when expressed as percentages, by reducing biases caused by intertaxonomic differences in pollen productivity, dispersal, and depositional characteristics. All chronologies are based on calibrated years BP (cal yr BP) and ages are given in cal yr BP, abbreviated to 'BP'. Twenty-five consecutive time windows over the last 11,700 years BP are used as in the LANDCLIM project (Gaillard et al., 2010; Trondman et al., 2015), i.e. 0-100, 100-350, 350-700 BP for the three first time windows, and 500 calendar years each from 700 to 11,700 BP. The methodological protocol for running REVEALS follows LANDCLIM (Trondman et al., 2015). The dataset of PPE and fall speed of pollen used for the 25 plant taxa correspond to the LANDCLIM standard 2 dataset of Mazier et al. (2012) (Table 1). The interpretation of RVs follows the rule applied by, for example, Trondman et al. (2015) - i.e. the RV of taxon $i(\mathrm{RV} i$ ) is considered to be reliable when its standard error ( $\mathrm{SE} i$ ) is smaller than $\mathrm{RV} i$ ( $[\mathrm{RV} i-\mathrm{SE} i]>0)$. The effect of site types and sizes on the percentage of $(\mathrm{RV} i-\mathrm{SE} i)>0$, was also tested (Appendix B, Table B-1).

\subsection{Land-use and climate effects on vegetation composition}

\subsubsection{The explanatory variables}

Two sets of explanatory variables independent of the pollen data are used in the statistical analyses - model-simulated climate and land-use variables. All analyses were implemented using CANOCO 5 for Windows (Šmilauer and Lepš, 2014).

As a climate variable, we used the combined effects of mean annual temperature $(\mathrm{T})$ and precipitation $(\mathrm{P})$. Temperature and precipitation data are available from the Earth System Model (ESM, Schurgers et al., 2006; Mikolajewicz et al., 2007) at $0.5^{\circ} \times 0.5^{\circ}$ spatial and centennial time resolutions for the last 9000 years (see Appendix C for more details). Temperature and precipitation do not necessarily replicate such limiting factors on vegetation growth as growing season or moisture availability, but they capture efficiently the major trends of Holocene climate changes (Appendix C). Simulated temperature and precipitation were the only available recent climate data that we could use at the spatial and temporal scales of our study.

The KK10 scenario of anthropogenic deforestation (Kaplan et al., 2009 ) is used as a land-use variable. KK10 simulates the fraction of deforested land based on the relationship between estimates of human population density and land-use area per capita, land suitability for cultivation and pasture, and assumptions on the

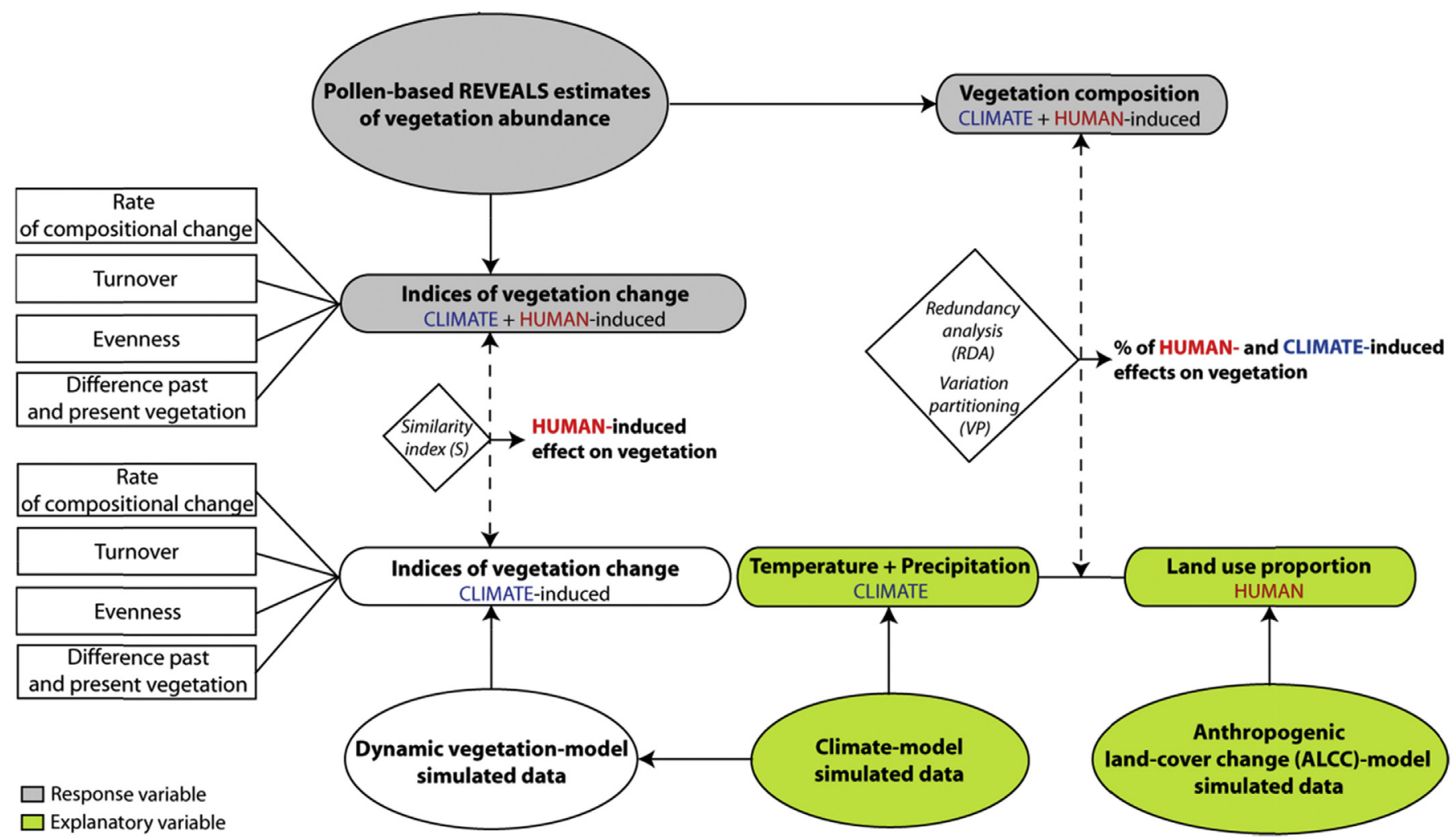

Fig. 2. Flow chart of the methodological approach. 
Table 1

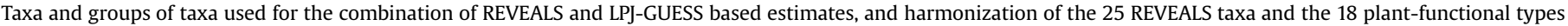

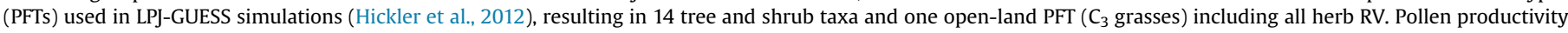

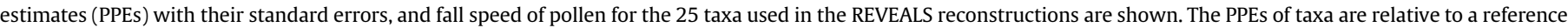
taxon, in this case Gramineae (PPE = 1). Botanical nomenclature follows Flora Europaea (Tutin et al., 1964-1980).

\begin{tabular}{|c|c|c|c|c|}
\hline REVEALS taxa & PPE and standard errors & Fall speeds of pollen $(\mathrm{m} / \mathrm{s})$ & LPJ-GUESS PFT & Taxa and groups of taxa used in this paper \\
\hline \multicolumn{5}{|l|}{ Trees and tall shrubs } \\
\hline Abies & $6.88 \pm 1.44$ & 0.12 & Abies alba & Abies \\
\hline Alnus & $9.07 \pm 0.1$ & 0.021 & Alnus & Alnus \\
\hline Betula & $3.09 \pm 0.27$ & 0.024 & $\begin{array}{l}\text { Betula pendula } \\
\text { Betula pubescens }\end{array}$ & Betula \\
\hline Carpinus & $3.55 \pm 0.43$ & 0.042 & Carpinus betulus & Carpinus \\
\hline Corylus & $1.99 \pm 0.19$ & 0.025 & Corylus avellana & Corylus \\
\hline Fagus & $2.35 \pm 0.11$ & 0.057 & Fagus sylvatica & Fagus \\
\hline Fraxinus & $1.03 \pm 0.11$ & 0.022 & Fraxinus excelsior & Fraxinus \\
\hline Juniperus & $2.07 \pm 0.04$ & 0.016 & Tall shrubs evergreen & Juniperus \\
\hline Picea & $2.62 \pm 0.12$ & 0.056 & Picea abies & Picea \\
\hline Pinus & $6.38 \pm 0.45$ & 0.031 & Pinus sylvestris & Pinus \\
\hline Quercus & $5.83 \pm 0.15$ & 0.035 & $\begin{array}{l}\text { Quercus pubescens } \\
\text { Quercus robur }\end{array}$ & Quercus \\
\hline Salix & $1.22 \pm 0.11$ & 0.022 & Tall shrubs summergreen & Salix \\
\hline Tilia & $0.8 \pm 0.03$ & 0.032 & Tilia cordata & Tilia \\
\hline Ulmus & $1.27 \pm 0.05$ & 0.032 & Ulmus glabra & Ulmus \\
\hline Dwarf shrubs & & & & Open land \\
\hline $\begin{array}{l}\text { Calluna vulgaris } \\
\text { Herbs }\end{array}$ & $0.82 \pm 0.02$ & 0.038 & Low shrubs evergreen & \\
\hline Artemisia & $3.48 \pm 0.2$ & 0.025 & $C_{3}$ grass & \\
\hline Cerealia-t & $1.85 \pm 0.38$ & 0.06 & $C_{3}$ grass & \\
\hline Cyperaceae & $0.87 \pm 0.06$ & 0.035 & $\mathrm{C}_{3}$ grass & \\
\hline Filipendula & $2.81 \pm 0.43$ & 0.006 & $C_{3}$ grass & \\
\hline Gramineae & $1 \pm 0$ & 0.035 & $C_{3}$ grass & \\
\hline Plantago lanceolata & $1.04 \pm 0.09$ & 0.029 & $C_{3}$ grass & \\
\hline Plantago media & $1.27 \pm 0.18$ & 0.024 & $C_{3}$ grass & \\
\hline Plantago montana & $0.74 \pm 0.13$ & 0.03 & $C_{3}$ grass & \\
\hline Rumex acetosa-t & $2.14 \pm 0.28$ & 0.018 & $C_{3}$ grass & \\
\hline Secale cereale & $3.02 \pm 0.05$ & 0.06 & $C_{3}$ grass & \\
\hline
\end{tabular}

location/characteristics of the land used initially, as well as geographical disparities in technological advances. KK10 simulations are modelled expressions of land-cover change as a consequence of land use, which provides fractions of anthropogenic deforestation at an annual resolution over the past 8000 years at a $0.5^{\circ}$ spatial scale. We up-scaled the spatial resolution of the KK10 scenario to $1^{\circ}$ by summing the fractions of deforestation and rescaling to a total sum of 1 . KK10 is used rather than the HYDE scenario (Klein Goldewijk et al., 2011), on the basis of a recent comparison between KK10, HYDE 3.1, and pollen-based REVEALS estimates of landscape openness in northern Europe (Trondman et al., 2012). KK10 was chosen because it better matched the REVEALS estimates for landscape openness (e.g. Pirzamanbein et al., 2014). Information about the input data for KK10 runs is provided in Kaplan et al. (2009). Note that the KK10 data do not extend beyond $8000 \mathrm{BP}$.

The implications and draw-backs of land-use scenario and model-simulated climate variables need to be considered. Thus, i) the KK10 dataset is highly dependent on the population estimates that are nation-dependent (e.g. Boyle et al., 2011); ii) the simulated climate variables do not account for all possible climate drivers on vegetation, but they represent a major part of the climate system; iii) the ESM simulation is one possible scenario of past climate and not a reconstruction; and iv) comparisons between GCM simulations and palaeoecological reconstructions of Holocene climate have shown seasonal and spatial discrepancies between the two (Hargreaves et al., 2013; Mauri et al., 2014; Harrison et al., 2015). Both simulated and proxy-based climate data have their own critical issues. The GCM-simulated climate variables provide general trends in Holocene climate change that are comparable with climate reconstructions from palaeoecological records, and we consider them appropriate for the purposes of our analyses.

\subsubsection{Redundancy analysis (RDA) and Monte Carlo tests}

The percentage of spatial variation in RV explained by both climate and land-use variables was assessed for all time windows in the five regions $\mathrm{A}-\mathrm{E}$ by a constrained (canonical) linear-based ordination method (= multivariate linear regression, RDA). The gradient lengths are less than two standard deviations (SD) of compositional turnover, as calculated using detrended correspondence analysis, for each of the five regions, and thus models assuming linear responses (redundancy analysis RDA) are appropriate (Śmilauer and Lepš, 2014). The RV data were square-root transformed to stabilise their variances. A Monte Carlo test, with 999 unrestricted permutations, was applied to assess the statistical significance ( $p$-value) of the percentages of RV spatial variation explained by the climate and land-use variables. The algorithm permutes the cases in the response data (RV) table while keeping the explanatory data intact (Šmilauer and Lepš, 2014). The null hypothesis being tested is that variation in RV is independent of changes in the climate and the land-use variables. The spatial and temporal resolutions of data have been taken into account to test this null hypothesis using a set of statistical analyses (see below and Table 2).

\subsubsection{Variation partitioning and Monte Carlo tests}

Variation partitioning (e.g. Legendre, 2008) was used to estimate the spatial, spatio-temporal, and temporal variations in the RV dataset explained by each individual explanatory variable (climate or land use) and by both variables together. This analysis was performed for:

1. The consecutive time windows of the Holocene (to explore spatial variation) for which RVs were calculated for i) the entire study area or ii) regions $\mathrm{B}$ and $\mathrm{C}$ together. 
Table 2

Set of statistical methods and the null hypotheses being tested. RV: REVEALS estimates.

\begin{tabular}{|c|c|c|c|c|}
\hline Data sources & Resolutions & $\begin{array}{l}\text { Statistical } \\
\text { methods }\end{array}$ & Abbreviations & Null hypotheses \\
\hline $\begin{array}{l}\text { Individual time } \\
\text { window }\end{array}$ & Spatial & $\begin{array}{l}\text { Redundancy } \\
\text { analysis }\end{array}$ & RDA & RV variation is spatially independent of changes in the climate and the land-use variables \\
\hline $\begin{array}{l}\text { Individual time } \\
\text { window }\end{array}$ & Spatial & $\begin{array}{l}\text { Variation } \\
\text { partitioning }\end{array}$ & VP & RV variation is spatially independent of changes in the climate and the land-use variables \\
\hline All time windows & $\begin{array}{l}\text { Spatial and } \\
\text { temporal }\end{array}$ & $\begin{array}{l}\text { Variation } \\
\text { partitioning }\end{array}$ & VP & $\begin{array}{l}\text { RV variation is spatially and temporally independent of changes in the climate and the land- } \\
\text { use variables }\end{array}$ \\
\hline $\begin{array}{l}\text { Individual } \\
\text { grid cell }\end{array}$ & Temporal & $\begin{array}{l}\text { Variation } \\
\text { partitioning }\end{array}$ & VP & RV variation is temporally independent of changes in the climate and the land-use variables \\
\hline
\end{tabular}

2. The entire Holocene for i) all regions together (to explore spatiotemporal variation), ii) each of regions A-E separately (to explore spatio-temporal variation), and iii) each grid cell separately (to explore temporal variation).

As the gradient lengths were moderate in all analyses (varying between 1.6 and 3.1SD), RDA was used for variation partitioning. Variation is expressed as the percentage explained by each explanatory variable, and by both variables together. $P$-values are estimated for each explanatory variable using the same Monte Carlo test as for the RDA.

\subsection{Land-use effect on indices of vegetation change}

\subsubsection{Dynamic vegetation modelling}

We employed LPJ-GUESS (Smith et al., 2001), a dynamic vegetation model that simulates potential natural vegetation cover in terms of major species or plant-functional types expected to be found in a certain area given climate conditions and history, soils and atmospheric $\mathrm{CO}_{2}$ concentrations (Table 1 ). The model provides an independent vegetation dataset for comparison with RVs. Details about the performance of LPJ-GUESS, the set-up and upscaling of the model runs, and the major differences between RVs and LPJ-GUESS vegetation (LPJGV), are given in Appendix C.

\subsection{2. $R V$ - and LPJGV-based indices of vegetation change}

The following indices have been calculated as described in Marquer et al. (2014):

- Rate of compositional change (Jacobson and Grimm, 1986) to identify periods of stability and change in vegetation.

- Turnover, representing the magnitude of vegetation compositional change through time (cf. Vellend, 2001; Birks and Birks, 2008). A square-root transformation of the response data was applied. The larger the range of the sample scores, the lower the number of taxa in common between successive time windows, and thus turnover is greater.

- An evenness (equitability) index which quantifies how numerically equal the taxa are in their abundances (Magurran, 2004). Maximum evenness equals 1.

- The dissimilarity between past and present vegetation over time based on the squared chord distance (SCD) between the modern time-window (0-100 BP) and each Holocene time window (SCD past-present).

Note that the indices above are calculated using 15 taxa or groups of taxa ('arable land' is excluded). The restricted number of taxa is due to the limited number of plant taxa that LPJ-GUESS can simulate, and for which pollen-productivity estimates are available for the REVEALS calculations. Individual herb taxa cannot be simulated by LPJ-GUESS and are represented by the PFT ' $C_{3}$ grass' for Europe (Table 1). We refer to either RV or LPJGV evenness to distinguish clearly these measures from 'floristic evenness' or 'palynological evenness' which would be based on a much higher number of plant taxa.

The differences between RV- and LPJGV-based indices of vegetation change are assessed using a similarity index (S) (see Appendix $C$ for details). $S=1$ if RV and LPJGV are equal (i.e. maximum similarity). CONISS cluster analysis (Grimm, 1987; as implemented in TILIA V.1.7.16) was applied to identify simultaneous changes in all S-indices. Note that S-indices are calculated individually for each index.

\section{Results}

\subsection{Grid-based REVEALS estimates}

For the 36 grid cells and all time windows, the percentages of reliable REVEALS estimates ((RVi-SEi)>0) are high (minimum $>80 \%$ ) other than for a few grids (Appendix B, Table B-2). We also examined the effect of site type (large lake, small sites or all sites) on the percentages of $(\mathrm{RV} i-\mathrm{SE} i)>0$ for eight grid cells with a sufficient number of sites of different type (Appendix B, Table B-1). The results show that the percentages are generally high and are lowest when only small sites are used rather than a single large lake, with or without small sites. These results suggest that the pollen dataset used here is appropriate for the application of the REVEALS model.

The grid-based REVEALS estimates (Fig. 3) for the major tree and shrub taxa clearly show the recognised Holocene succession of increased abundances of trees and shrubs, and the late-Holocene increase in landscape openness. At ca. $11,700 \mathrm{BP}$, the proportion of open land is high and Pinus (pine) and Betula (birch) are dominant across most of the study area. From 10,500 BP, abundances of Corylus (hazel) and Ulmus (elm) increase in most regions, before the rise in Quercus (oak), Tilia (lime), Alnus (alder), and Fraxinus (ash) from $9500 \mathrm{BP}$, although Tilia increases late in regions C (8000 BP) and E (6500 BP). Picea (spruce) expands from 8500 BP in Region A, 8000 BP in Region C, and 3500 BP in Region D. Abies (fir) increases from $8500 \mathrm{BP}$ in Region A, and occurs with low values from $3500 \mathrm{BP}$ in Region B. Fagus (beech) expands from, respectively, 7000, 4500, 1500 BP in regions A, B, and C. Carpinus (hornbeam) rises from 3500 BP in Region B. Woodland vegetation is impacted by deforestation from $6000 \mathrm{BP}$ in most regions, as evidenced by the general increase in open land, and over the last 1500 years as a consequence of the expansion of arable land (represented by Cerealia- $t$ and Secale cereale).

Of the indices of vegetation changes (Fig. 3), RV rate of change is the highest at the beginning of the Holocene and during the last 2000 years. Turnover decreases progressively from 10,000 to $9000 \mathrm{BP}$ to present. RV evenness increases gradually to attain highest values ca. 7500 BP and then decreases in most regions, but 

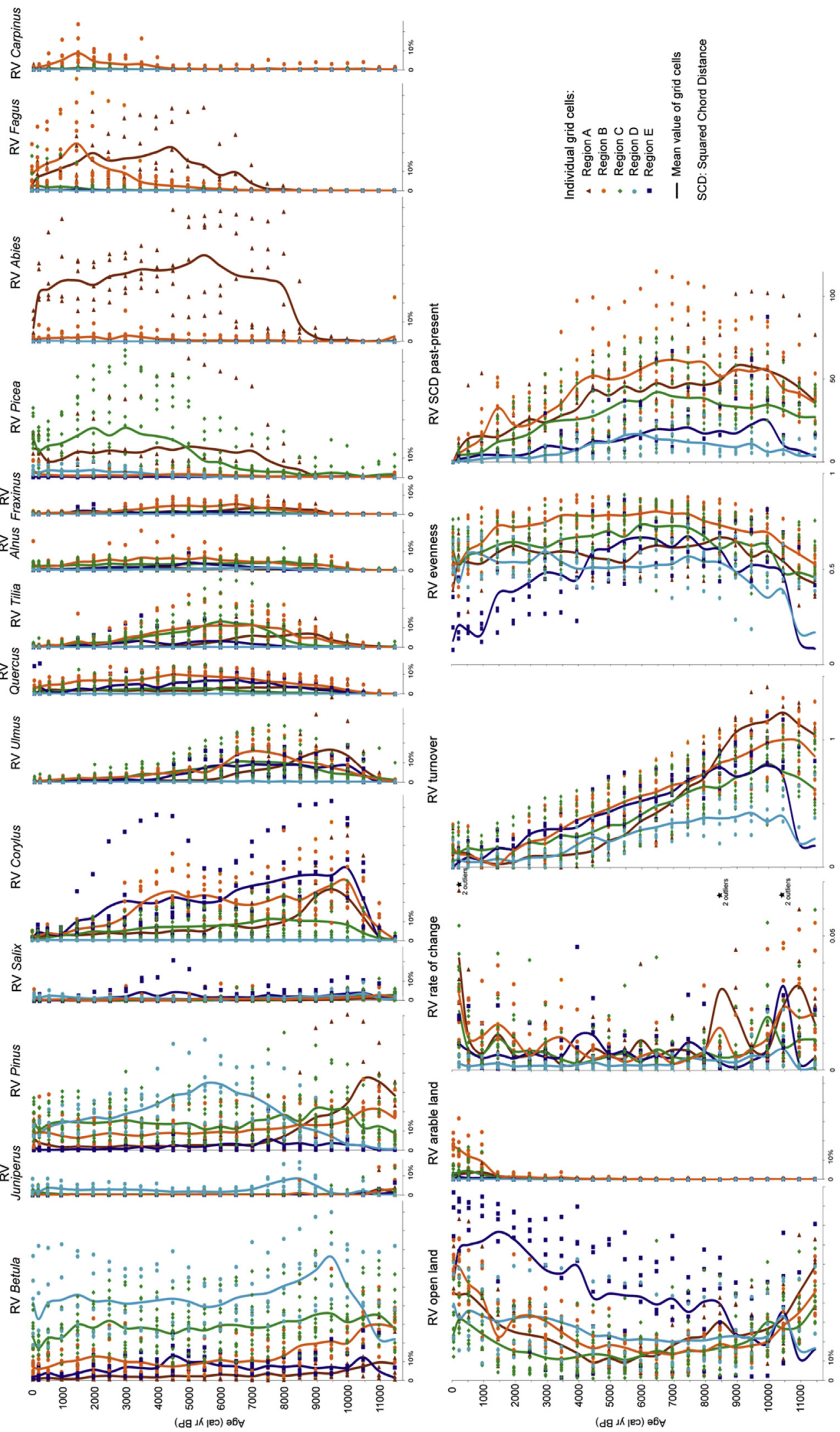

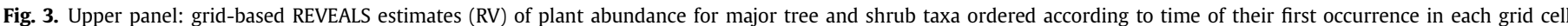

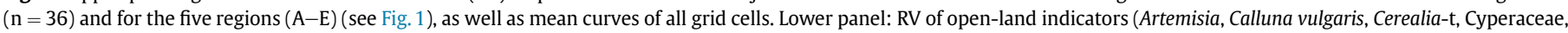

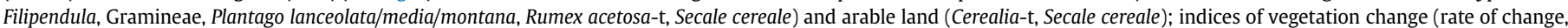

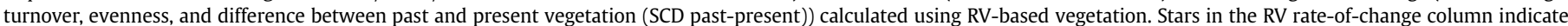
outliers included in the calculations. See main text for further explanation. A spline function has been used to smooth the trend lines. 
high values are maintained until 1500 BP except for Region E, where it decreases from $4500 \mathrm{BP}$ and drops abruptly at $1500 \mathrm{BP}$. RV SCD past-present indicates that similarity between past and present vegetation increases gradually from $4500 \mathrm{BP}$.

\subsection{Land-use effect on vegetation based on the similarity $R V-L P J G V$ indices}

The S-values quantify the similarity between the RV and LPJGV indices. They were used in CONISS to identify periods when land use might have influenced vegetation change; i.e. periods with low similarity indicate an impact of human activities on vegetation. The results (Fig. 4) highlight two major periods (I-II), each divided into two sub-periods (A and B). Sub-period I.A is also separated into two phases, $a$ and $b$, although we describe hereafter sub-period I.A as a whole.

Period I starts at 9000 BP with sub-period I.A (ca. 9000-4500 BP) characterised by high similarity for turnover and evenness in all regions. From 5000 to 4500 BP, S decreases in some regions. Similarity for SCD past-present decreases in most regions over period I.A. For rate of change, it gets low values between 9000 and $7000 \mathrm{BP}$, higher values between 7000 and $5500 \mathrm{BP}$, and low values again until 4500 BP. Sub-period I.B (ca. 4500-2000 BP) exhibits a reduction in similarity for turnover in all regions, for evenness in Region E, and for SCD past-present in most regions (Svalues for SCD past-present increase in regions $B$ and $C$ at $3000 \mathrm{BP}$ ). Similarity for rate of change follows an increasing trend in most regions until $2500 \mathrm{BP}$.

Period II starts with sub-period II.A (ca. 1500-500 BP), corresponding to a general decrease in similarity for turnover and a slight decrease for evenness in all regions (except in region $\mathrm{E}$ where it is strong), a general increase in rate of change (except in Region D), and a stabilisation or rise of SCD past-present (except in Region E). Sub-period II.B (the last 500 years) exhibits a reduction in similarity for rate of change (except in Region D), evenness in regions $\mathrm{A}$ and $\mathrm{E}$, turnover in Region $\mathrm{E}$, and $\mathrm{SCD}$ past-present in all regions. Similarity, however, increases for turnover in regions $A, B$, $C$, and D, and increases only slightly for evenness in regions $B, C$, and $\mathrm{D}$.

\section{3. $R V$ variation explained by climate and land use}

\subsubsection{The explanatory variables}

The simulated estimates of Holocene changes in the climate variables of temperature $(\mathrm{T})$ and precipitation $(\mathrm{P})$ are presented in Fig. 5. Temperature decreases progressively through the Holocene in the entire study area, with similar warm and cold anomalies except in Region $\mathrm{E}$, where $\mathrm{T}$ does not change substantially until the Little Ice Age (LIA). Warm anomalies are seen in the intervals $5000-4000,3000-2500$, and 1500-1000 BP. The major cold anomaly is the LIA, followed by those at 3500 and 2000 BP. Temperature increases in all regions after $250 \mathrm{BP}$. Precipitation shows a progressive decrease in regions $A$ and $E$, while there are minor changes in regions $\mathrm{B}, \mathrm{C}$, and $\mathrm{D}$. $\mathrm{P}$ increases in regions $\mathrm{B}$ and $\mathrm{A}$ from 500 and $250 \mathrm{BP}$, respectively.

Holocene changes in the land-use variable show a progressive increase of deforestation from 8000 until 2500 BP (3000 BP in Region A) in all regions except Region D. The increase is slowest in Region $C$ and landscape openness is greatest in Region A. From 2500 BP (3000 BP in Region A), deforestation increases more rapidly until $250 \mathrm{BP}$ in all regions (except Region $\mathrm{D}$ ). Deforestation decreases during the last 100 years in regions $\mathrm{A}, \mathrm{B}$, and C.

\subsubsection{Effects of climate and land use based on RDA}

The term "good predictor" used below and in the next sections refers to those explanatory variables with $p$-values $<0.05$ that have been estimated in the RDA permutations that test the null hypotheses (Table 2). $P$-values evaluate the statistical significance of the test whereas the percentages of explained variation are a measure of how much the explanatory variable explained changes in RV variation. $P$-values and percentages of explained RV variation are two different but complementary types of information.

The effect of climate based on RDA is shown in Fig. 6. The results indicate that in Region A, climate is a good predictor (most $p$-values $<0.05$ ) of RV variation during $9000-8500$ and $5500-200 \mathrm{BP}$, with the percentages of RV variation explained being high (39-67\%). In Region B, climate is also a good predictor until 3000 BP with $18-55 \%$ of RV variation explained. After $3000 \mathrm{BP}$, climate is not a good predictor with only $10-21 \%$ of RV variation explained. In Region C, climate is a good predictor until $4000 \mathrm{BP}$ and for the last 500 years, with $11-37 \%$ of the RV variation being explained before $4000 \mathrm{BP}, 10-18 \%$ for the period $4000-500 \mathrm{BP}$ and $17-26 \%$ for the last 500 years. In Region D, climate is a good predictor up to $2000 \mathrm{BP}$ and $37-65 \%$ of the RV variation is explained until then, while it is not a good predictor from $2000 \mathrm{BP}$ with $36-52 \%$ of RV variation explained. In Region E, climate is not a good predictor for the entire Holocene. Here, the RV variation explained by climate varies between 8 and 57\% from 9000 to 2000 BP, rising to $28-54 \%$ over the last 2000 years.

The effect of land use is also shown in Fig. 6. RV variation explained by land use increases in all regions from 7000 (E), 6500 $(\mathrm{A}, \mathrm{B})$ and $6000-5500 \mathrm{BP}(\mathrm{C}, \mathrm{D})$, attains maximum values, 67\% (A, $2000 \mathrm{BP}$ ), 43\% (E, $3000 \mathrm{BP}), 30 \%$ (B, $3500 \mathrm{BP}), 30 \%$ (D, $5500 \mathrm{BP})$ and $24 \%$ (C, $5000 \mathrm{BP}$ ), then decreases. The exception is Region $\mathrm{E}$, where values are low between 2500 and $1500 \mathrm{BP}$ and then increase to a profile maximum of $63 \%$. In Region $A$, land use is a good predictor (most $p$-values $<0.05$ ) of RV variation from 5500 BP. In Region B, land use is a good predictor until $1500 \mathrm{BP}$. In Region C, land use is a good predictor only between 5500 and 4500 BP. In Region D, land use is not a good predictor for the entire Holocene, and in Region E, it is a reliable predictor only at $250 \mathrm{BP}$.

Climate explains a higher percentage of RV variation than land use until 6000 (A), 5500 (C) and $4000 \mathrm{BP}$ (B), and for the entire Holocene in Region D. In regions $A$ and $B$, land use is a better explanation of RV variation than climate until 1500-1000 BP. In Region C, land use is a better explanation of RV variation at 5000, 3000 and $1500 \mathrm{BP}$. In that region, the explanations of RV variation by climate and land use are very similar until $1000 \mathrm{BP}$. The last 1000 years are characterised by a new dominance of climate over land use in regions A, B and C, although land use is again dominant for the last century in Region A. In Region E, climate has lower explanation of RV variation than land use for most of the last 8000 years: climate explains higher percentage of RV variation than land use only at $1500 \mathrm{BP}$; however, for most of the Holocene, neither are significant predictors in this region.

\subsubsection{Effects of climate and land use based on variation partitioning}

Variation partitioning (VP) results performed for the entire study area and regions $\mathrm{B}+\mathrm{C}$ are presented in Fig. 6 . The average percentage of unexplained variation over the Holocene is $60 \%$ (entire area) and 58\% (regions $\mathrm{B}+\mathrm{C}$ ). Land use is a stronger predictor (most of $p<0.05$ or $<0.1$ ) than climate through most of the Holocene. Climate explains most RV variation from $8000 \mathrm{BP}(36 \%$ entire area; $29 \%$ regions $B+C$ ) to recent times (100-0 BP: $16 \%$ entire area; $27 \%$ regions $B+C$ ). There is a marked increase at ca. $250 \mathrm{BP}$, with $44 \%$ for regions B $+\mathrm{C}$. Land use explains only a small fraction of RV variation (2.5-6\% entire area; $2-10 \%$ regions $B+C$ ) through the Holocene. For the whole study area, there is an increase of RV variation explained by land use between 3000 and $2000 \mathrm{BP}, \mathrm{a}$ 

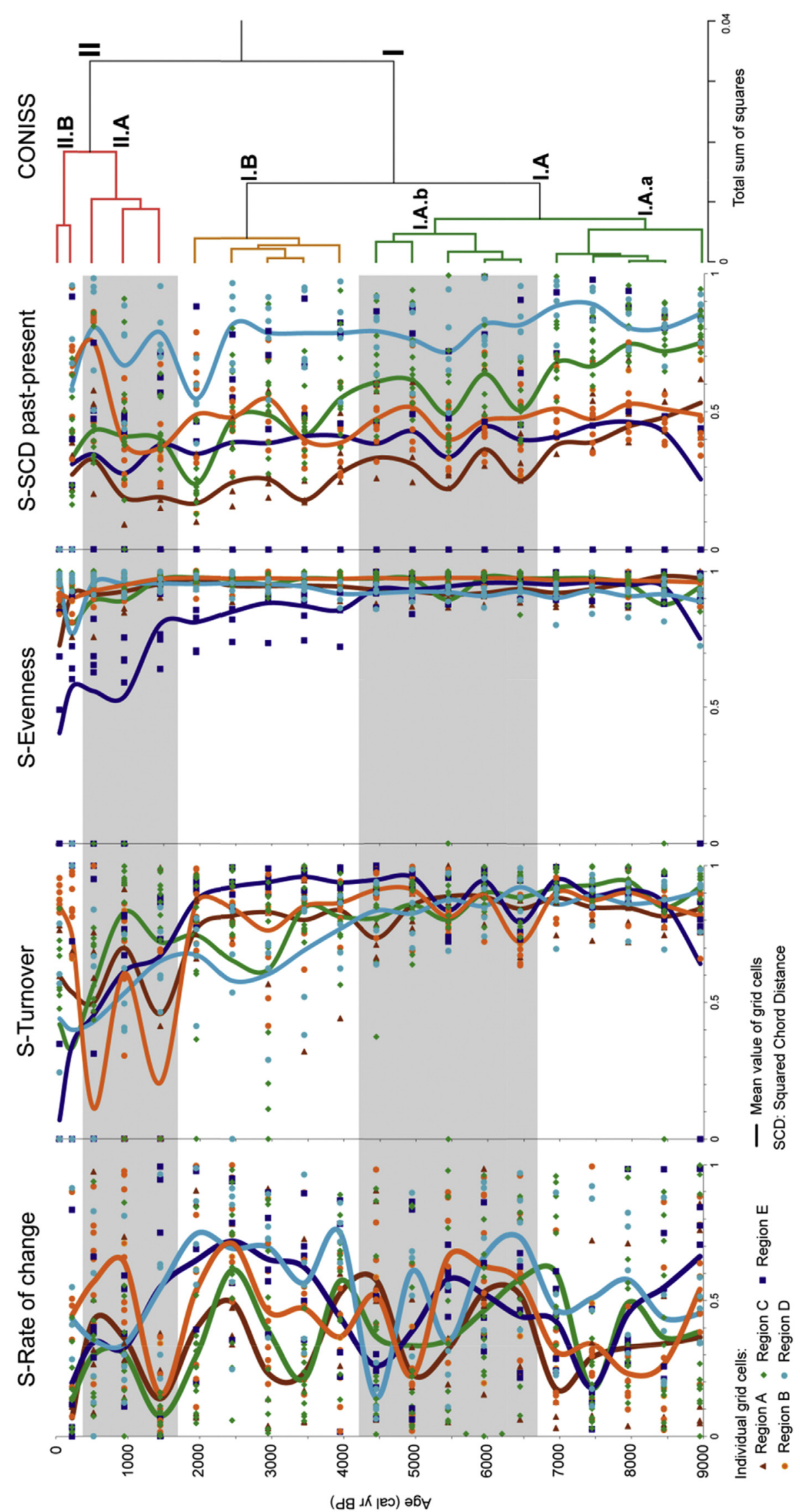

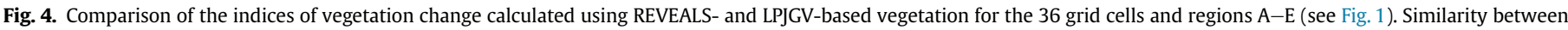

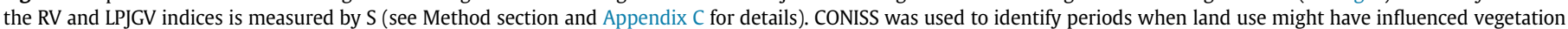
change (i.e. periods with low similarity indicate the impact of human activities on vegetation). A spline function has been used to smooth the trend lines. 
decrease until $250 \mathrm{BP}$, and a rise again to the present. For regions $\mathrm{B}+\mathrm{C}$, the trend is one of a decrease until $6500 \mathrm{BP}$, a slight enhancement until $4000 \mathrm{BP}$, then a fall to $500 \mathrm{BP}$ followed by an increase to the present. Percentages of RV variation explained by land use and climate combined increase steadily from 8000 to 3500 BP (3-10\% entire area; $0.5-5 \%$ regions $B+C)$, a further rise from $3500 \mathrm{BP}$ to $500 \mathrm{BP}(10-21 \%$ entire area; $5-28.5 \%$ regions $\mathrm{B}+\mathrm{C})$, and a decrease to the present. There is a strong increase at ca. $3000 \mathrm{BP}$ for regions $\mathrm{B}+\mathrm{C}$.

The VP results for the entire Holocene and $\mathrm{i}$ ) all regions together and ii) each region A-E separately, are presented in Fig. 7. They show that in general only a small part of the variation is explained by climate and land use. Climate explains more of the variation than land use for all regions taken together and for regions A, C, and D, while land use explains more of the variation in regions $B$ and $E$. The interactions of climate and land use do not explain much of the variation in most regions. When the whole Holocene is considered, climate has a significant effect in Region B and land use in Region C.

VP results performed for the entire Holocene and each grid cell separately are presented in Table 3 . They show a generally higher percentage of variation explained by climate and land use than VP applied by region (Fig. 7), i.e. the percentage of unexplained variation is lower. The results agree with the analysis by region with respect to which explanatory variable explains most of the variation. Some differences are, however, observable. For Region A, land use explains most of the variation in all grid cells except one; although the effect of land use is not statistically significant, while the effect of climate is significant in all grid cells. For Region $C$, the explanation from climate and land use is more differentiated, as well as their apparent significance. For Region D, land use has a significant effect for three grid cells.

\section{Discussion}

This study shows that pollen-based REVEALS estimates of plant abundance are useful for the analysis of regional to subcontinental-scale vegetation change. The results suggest that the combination of LPJ-GUESS-simulated potential vegetation and pollen-based REVEALS estimates via a similarity index gives important information on the effects of past land use on Holocene vegetation and an identification of the critical phases of land-use impacts (Figs. 8 and 9). The use of simulated climate and landuse data in RDA and VP provides a quantification of their respective roles in Holocene vegetation, and thereby an assessment of whether climate was and is still a major controller of vegetation. All the results are summarised in Figs. 8 and 9 for the sub-continental area of northern and western Europe north of the Alps.

\subsection{Grid-based estimates}

The grid-based RV data (Fig. 3) exhibit similar patterns to those in Marquer et al. (2014), but with interesting differences discussed below. Although RV estimates inferred from pollen records of large lakes are more reliable and precise than those inferred from small sites (Sugita, 2007a; Trondman et al., 2016), it may be necessary to use RV data from multiple small sites for research questions requiring vegetation reconstructions over large areas (e.g. at the European scale, Trondman et al., 2015). We show here that the RV from grid-based multiple sites in our study area are generally reliable. Trondman et al. (2016) used pollen records from large lakes and small sites in southern Sweden and showed that the RVs from multiple small sites generally agree with estimates from large lakes. They did, however, have larger error estimates, which corroborated the tests performed with simulated data by Sugita (2007a).
The grid-based RV data are founded on the 25 major plant taxa for which we have reliable pollen-productivity estimates (Trondman et al., 2015). This has implications for the interpretation of RV-based indices, in particular RV evenness, which cannot be compared with palynological and floristic evenness (Odgaard, 2007; Berglund et al., 2008; Giesecke et al., 2014b; Birks et al., 2016). Palynological evenness includes all taxa identified in pollen assemblages and floristic evenness comprises all species present in the vegetation - a difference that should be borne in mind. This implies that the RV evenness corresponds to general trends in vegetation composition, whilst palynological and floristic evenness responds to vegetation changes at the taxon level. However, palynological evenness introduces biases in the results as it does not consider any corrections for the differential production and dispersal of pollen. The 25 plant taxa used to calculate RV evenness are the major ones and therefore account for a large part of the vegetation changes. Further discussion on the evenness estimates based on pollen data can be found in Matthias et al. (2015). Here we consider the RV evenness as an index of change in vegetation composition rather than a diversity index.

Differences between grid-based RV and LPJGV data may have various causes. Several studies have compared the results of ecosystem model simulations with pollen-accumulation rates and pollen percentages (e.g. Miller et al., 2008), or pollen-based RV (e.g. Pirzamanbein et al., 2014). The outputs from these may differ significantly during some periods of the Holocene. Pollen-based estimates typically include human-induced vegetation which is not the case for ecosystem model data. Other causes of differences include ecological processes such as tree migration (cf. Migrational lag in Picea and Fagus; Huntley et al., 1989) and soil development, which are not effectively modelled by ecosystem model simulations. Note that a recent study by Giesecke et al. (2017) suggests that the late Holocene expansions of Picea and Fagus might not be explained by migrational lag. Furthermore, the use of simulated rather than empirical records of past climate may further affect the results. However, Miller et al. (2008) show that many aspects of past change are captured by ecosystem model simulations. Acknowledging these limitations, it can be assumed that the more similar that RV and LPJGV indices are, the more the indices are likely to be controlled by climate, and the less by land use. More details on the differences between RV and LPJGV are presented in Appendix C.

The land-use and climate effects on grid-based vegetation estimates have been quantified using similar approaches to Reitalu et al. (2013) and Kuosmanen et al. (2016a, 2016b), although there are significant methodological differences between the studies; viz. i) the size of the study region, ii) the number of pollen records used for reconstruction, iii) the length of the period studied, iv) the indicators of land use and climate used as an explanatory variable. These previous studies mainly use single sites, and showed that site characteristics explain a relatively large part of the variation in RV estimates. As we use multiple sites for each individual grid-based $\mathrm{RV}$, we did not analyse the effect of site type and number on the outcomes. The results of Trondman et al. (2016) show that the number of sites can clearly be significant as an explanatory factor. The fact that the unexplained variation (60\%) is much larger in our analysis than in the study of Reitalu et al. (31\%) indicates that site characteristics may explain a large part of the variation. We also investigated the last 9000 years while Reitalu et al. (2013) examined the last 5000 years, and this may also contribute to differences in the results. Kuosmanen et al. (2016a, 2016b) assessed most of the Holocene (the last 9000 years) and likewise have a large unexplained variation in several cases (30-76\%). The size of the study region and the length of the period examined correspond to the spatial and temporal scales of the analyses. A large study region 


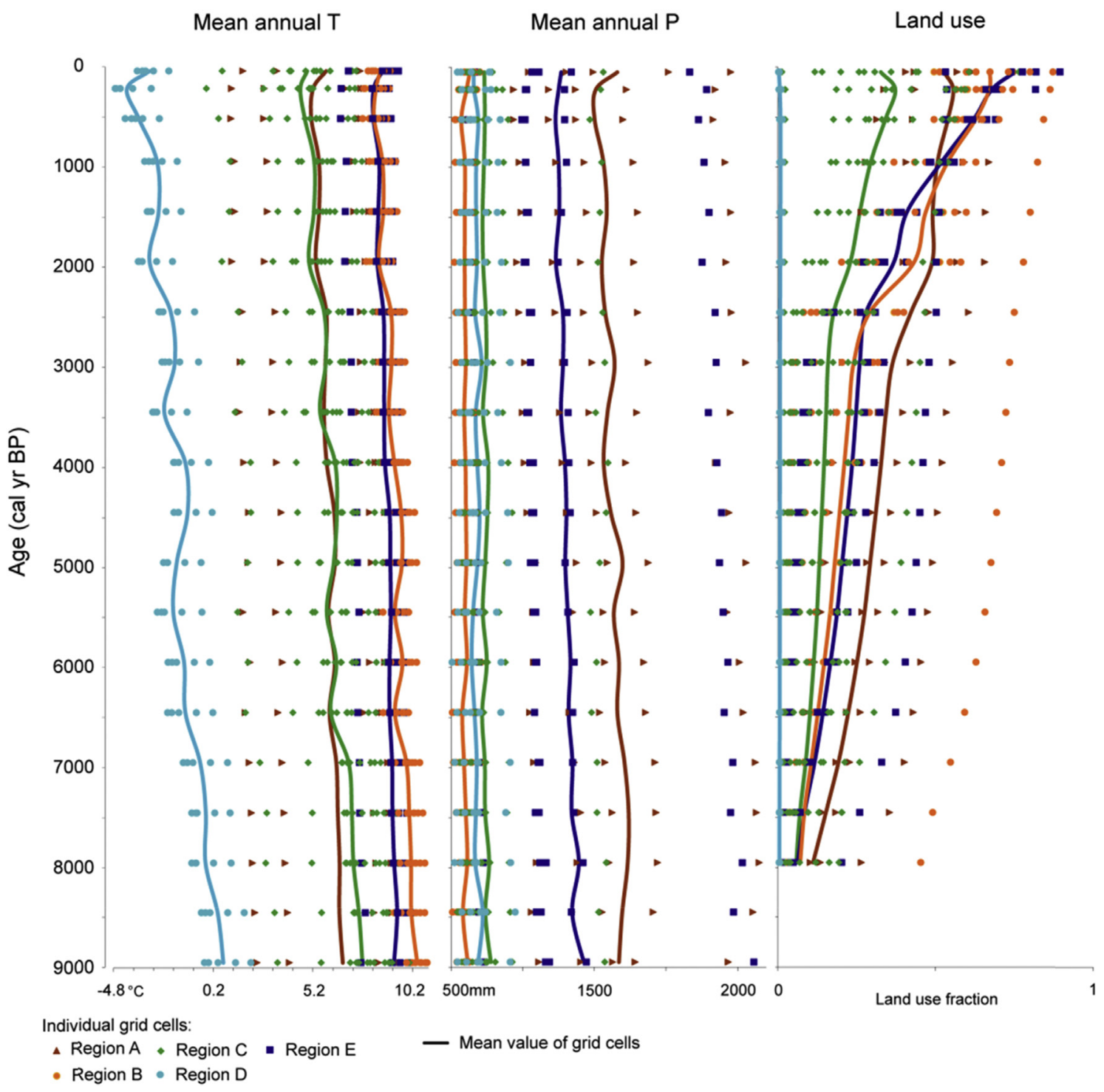

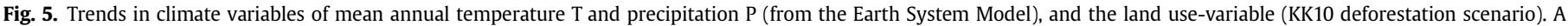
spline function has been used to smooth the trend lines.

across longer time period would introduce additional drivers of change that would need to be considered in the analyses, e.g. variation in soil types; this might partially explain the high unexplained variation. Further, as an indicator of land use, Reitalu et al. (2013) used pollen data from the same pollen records as those used to reconstruct forest composition. This implies that the land-use explanatory variable is not totally independent of the response variable, which may also reduce the unexplained variation in their results.

\subsection{Climate is the major driver of vegetation when the Holocene is considered as a whole}

It appears difficult to separate climate and land-use effects when the Holocene is considered as a whole (Fig. 7; Table 3). In particular, this is because all Holocene climate and human periods are considered together. In most cases, climate better explains vegetation composition than land use does. Furthermore, 15 grid cells indicate climate to be a good predictor (i.e. $p$-values $<0.05$ ) of Holocene vegetation, compared to 8 for land use. For all regions (where climate explains $11 \%$ and land use $6 \%$ ) or Region C (where climate explains $12 \%$ and land use $5 \%$, including Estonia, our results are similar to those of Reitalu et al. (2013; climate explains $10.2 \%$ and land use 3.8\%), although the combined effect of both indicators is very low in our study. For instance, in Region $C$, the combined effect of land use and climate based on individual grid cells ranges between 20 and $40 \%$, i.e. these results are closer to those of Reitalu et al. (21.3\%) than those from the VP using grid cells together. The estimates of Kuosmanen et al. (2016a) also confirm the role played by climate as a major control of vegetation changes; their estimates are, respectively, higher and lower than ours for climate (24.3\%)and land use (1.6\%) when all sites are employed for VP. Climate is therefore the main control of vegetation change when the Holocene is considered as a whole.

Regional variability indicates that in regions B (northern Germany, southern Sweden, Poland) and E (Great Britain, Ireland), respectively, there is a greater vegetational composition effect arising from land use (13 and $22 \%$ of the variation) than from climate (5 and 9\%). This seems logical, as regions B and $\mathrm{E}$ include the lowland areas of NW Europe with the largest changes in open land 


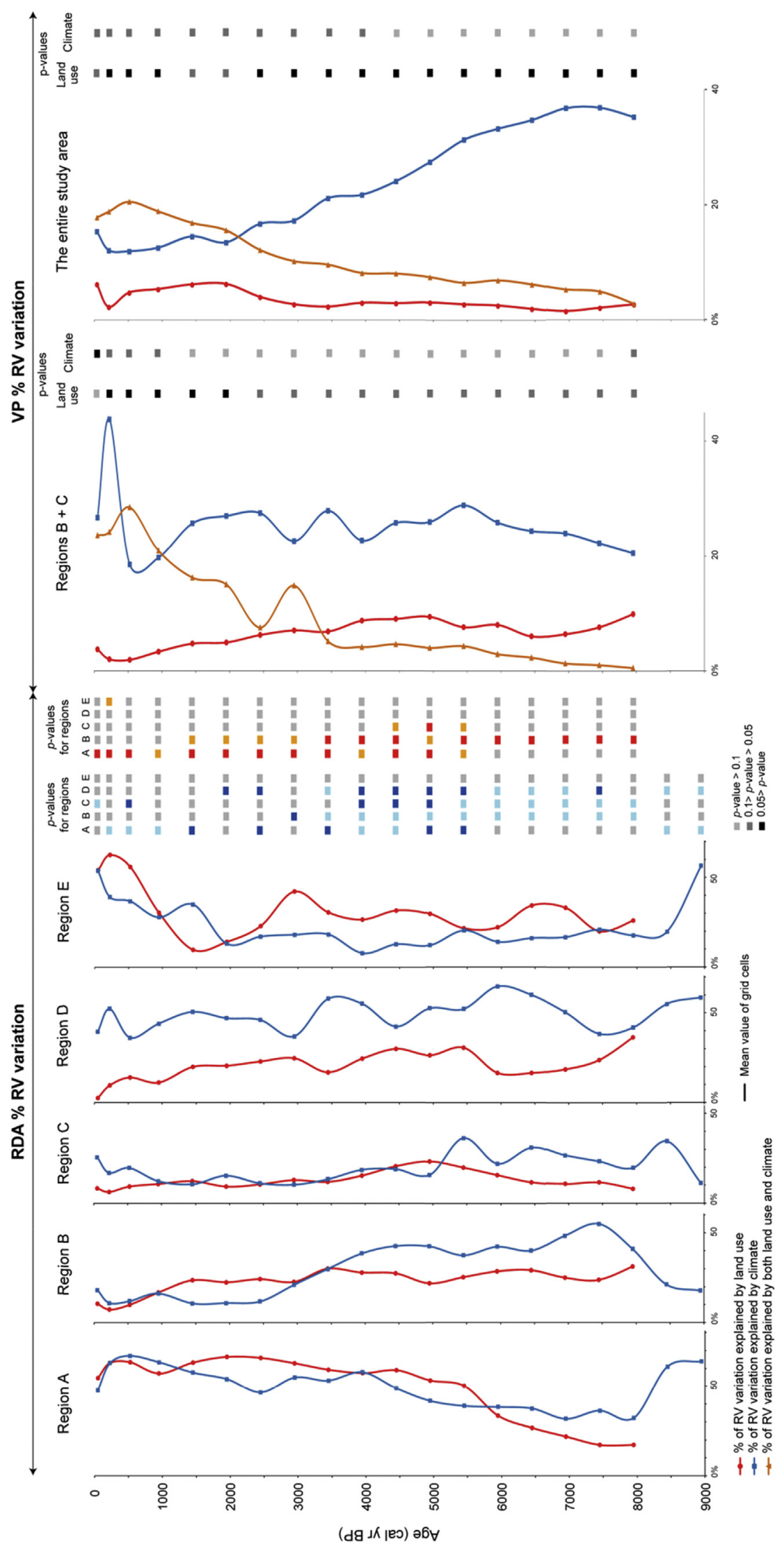

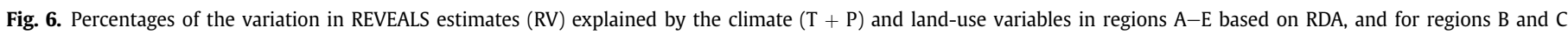

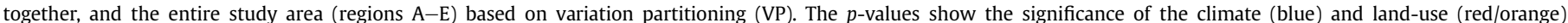

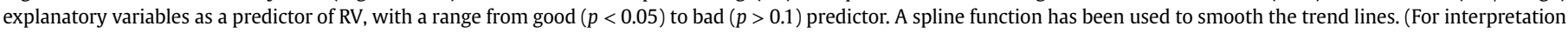
of the references to colour in this figure legend, the reader is referred to the web version of this article.) 


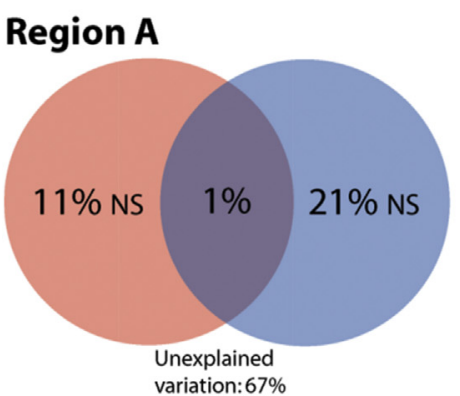

Region D

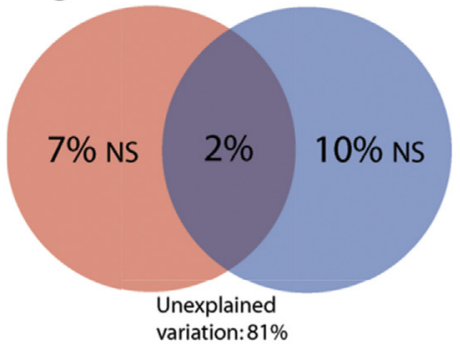

Land use

Climate

\section{Region B}

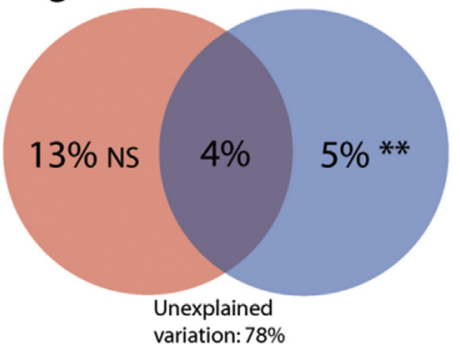

Region E

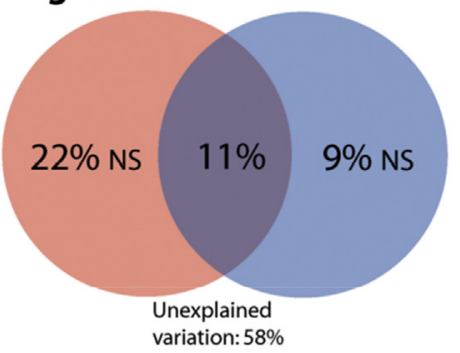

Region C

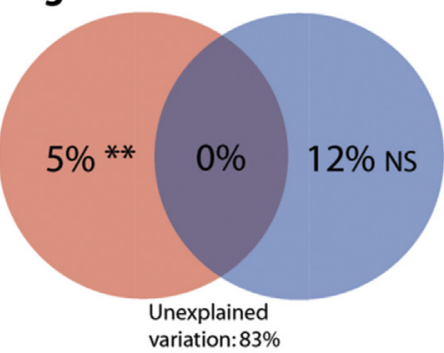

All regions

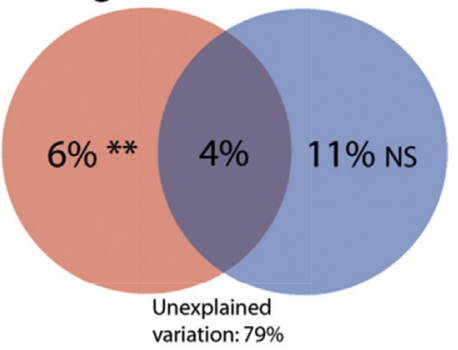

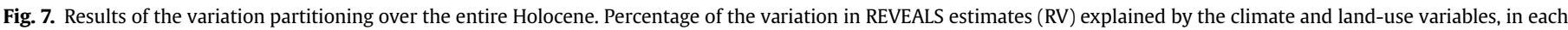

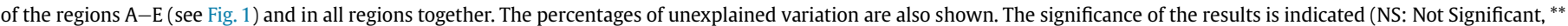
Significant $(p$-value $<0.05)$ )

extent developing from major agricultural impact, and they also feature areas which experience maritime rather than continental climate, rendering them less sensitive to climate change.

\subsection{Early effect of land use and climate controls vegetation at 7000-6500 BP}

The first impacts of land use on vegetation are recorded at 7000-6500 BP (1 in Fig. 8). At a sub-continental scale, this period corresponds to a slight acceleration (increase in rate of change) of vegetation changes, with the beginning of arable agriculture, a decrease of broadleaved forest and an expansion of coniferous woodland. These modifications cause the start of a gradual decrease in RV evenness at the sub-continental scale. At regional scales, slight decreases in RV evenness are found in regions $A, C$, and $\mathrm{E}$ from 6000 to $5000 \mathrm{BP}$. These results are consistent with a decrease in palynological evenness from 7000 to 6000 BP in Germany (Matthias et al., 2015). Note that the decrease in evenness in Germany is mainly due to an increase in rare taxa. We do not use rare taxa in our study. Vegetation composition also starts to be similar to today vegetation from this time (decrease in SCD pastpresent).

Land use is a good explanatory predictor for these changes in vegetation - the RDA \% RV variation explained increases in all regions from 7000 to 5500 BP (Fig. 6). From 6000 BP, land use becomes a significant predictor of vegetation (Fig. 9). The effects of land use on vegetation are confirmed by the RDA and VP analyses and the $S$ indices - all three land-use measures are enhanced from 7000 to 6500 BP (Fig. 9). VP, performed for regions B and C (Fig. 6), also supports this conclusion with an increase of land-use influence on vegetation at $6000 \mathrm{BP}$. Marquer et al. (2014) showed that the human impact on vegetation composition had started from ca. $6700 \mathrm{BP}$ at the sub-continental scale. However, that study suggested that the impact on vegetation of agricultural intensification and human population growth, indicated by rapid compositional change, large decrease in turnover, and stabilisation or decrease of RV evenness, is observed only from ca. 5200 BP. The present study highlights even earlier consequences for human activities on vegetation.

Deforestation, the rise of open land, appears to have started from $6500 \mathrm{BP}$ in regions B and D and from around $8500 \mathrm{BP}$ in Region $\mathrm{E}$. It has long been accepted that Neolithic forest clearances started to affect vegetation in central Europe from 7000 to $6000 \mathrm{BP}$ (e.g. Behre, 1988; Berglund et al., 1996). Other studies using pollenbased RVs (e.g. Nielsen et al., 2012; Lechterbeck et al., 2014) or pseudobiomisation (Woodbridge et al., 2014) also indicate an early human impact on regional land cover. Biomisation results suggest a decrease in forest cover for northern and central Europe around $7000 \mathrm{BP}$ (Davis et al., 2015). The beginning of farming is recorded at 7400 BP in central Germany and 6000 BP in northern Germany (Shennan et al., 2013). More particularly, our study shows that open land increases at the expense of most broadleaved trees (Ulmus, Corylus, Quercus, Tilia and Fraxinus) which supports the progressive decline in broadleaved forest from $6000 \mathrm{BP}$ observed by Fyfe et al (2015). It is important to note, of course, that the earliest reductions in woodland (and certainly in Britain and Ireland) are more likely to have resulted from Mesolithic rather than Neolithic activity, quite apart from considerations of animal grazing and forest openness (Vera, 2000; Mitchell, 2005; Smith and Whitehouse, 2010).

Neolithic agriculturalists started to have significant effects on vegetation in parts of the study area from 7000 to $6500 \mathrm{BP}$, whereas climate influence on plant abundance and composition gradually decreases from $7000 \mathrm{BP}$. However, climate remains the major driver of vegetation at the sub-continental scale, explaining $37 \%$ of the variation in vegetation composition at $7000 \mathrm{BP}$ against $1.5 \%$ for land use (see VP in Fig. 9). 
Table 3

Results of the variation partitioning for each grid cell and the whole Holocene. This table shows, for each grid cell, the percentages of variation in REVEALS estimates explained by the climate and land-use variables in each of the regions A-E (see Fig. 1). The significance of the results is indicated (NS: Not Significant, ${ }^{* *}$ Significant $(p$-value $<0.05))$.

\begin{tabular}{|c|c|c|c|c|}
\hline \multirow[t]{2}{*}{ Regions } & \multirow[t]{2}{*}{ Grid cells } & \multicolumn{3}{|c|}{$\begin{array}{l}\% \\
\text { of explained REVEALS variation } \\
\text { (and effect significance) }\end{array}$} \\
\hline & & Climate & Land use & $\begin{array}{l}\text { Both climate } \\
\text { and land use }\end{array}$ \\
\hline \multirow[t]{5}{*}{ A } & 1 & $4^{* *}$ & $23 \mathrm{NS}$ & 22.5 \\
\hline & 2 & $3.5^{* *}$ & $13 \mathrm{NS}$ & 54.5 \\
\hline & 3 & $3^{* *}$ & $7 \mathrm{NS}$ & 33 \\
\hline & 4 & $3^{* *}$ & $2.5^{* *}$ & 35.5 \\
\hline & 5 & $4^{* *}$ & $6.5 \mathrm{NS}$ & 35 \\
\hline \multirow[t]{9}{*}{ B } & 6 & $0.5 * *$ & 7 NS & 62 \\
\hline & 8 & $8.5 \mathrm{NS}$ & 11.5 NS & 17 \\
\hline & 9 & $12 \mathrm{NS}$ & $9.5 \mathrm{NS}$ & 37 \\
\hline & 11 & $18 \mathrm{NS}$ & $22 \mathrm{NS}$ & 18.5 \\
\hline & 12 & $3 * *$ & $12.5 \mathrm{NS}$ & 42 \\
\hline & 13 & $1.5^{* *}$ & 49 NS & 26.5 \\
\hline & 15 & $2^{* *}$ & 37 NS & 18.5 \\
\hline & 16 & $1^{* *}$ & 29 NS & 48.5 \\
\hline & 18 & $1^{* *}$ & $28 \mathrm{NS}$ & 28.5 \\
\hline \multirow[t]{12}{*}{$C$} & 17 & $12 \mathrm{NS}$ & $26 \mathrm{NS}$ & 4 \\
\hline & 20 & $2^{* *}$ & 17.5 NS & 31 \\
\hline & 21 & $3.5^{* *}$ & $7 \mathrm{NS}$ & 32 \\
\hline & 23 & $3.5 * *$ & 49 NS & 23 \\
\hline & 24 & $13.5 \mathrm{NS}$ & $18 \mathrm{NS}$ & 27 \\
\hline & 25 & $47 \mathrm{NS}$ & $4.5^{* *}$ & 0.5 \\
\hline & 26 & $16 \mathrm{NS}$ & $11 \mathrm{NS}$ & 28.5 \\
\hline & 27 & $15.5 \mathrm{NS}$ & $3^{* *}$ & 36.5 \\
\hline & 28 & $5^{* *}$ & $5^{* *}$ & 37.5 \\
\hline & 29 & $13 \mathrm{NS}$ & $9.5 \mathrm{NS}$ & 33 \\
\hline & 30 & $22.5 \mathrm{NS}$ & 13 NS & 17.5 \\
\hline & 31 & $28 \mathrm{NS}$ & $5.5 \mathrm{NS}$ & 8 \\
\hline \multirow[t]{5}{*}{$\mathrm{D}$} & 32 & $20 \mathrm{NS}$ & $2^{* *}$ & 3 \\
\hline & 33 & $28 \mathrm{NS}$ & $6 \mathrm{NS}$ & 2.5 \\
\hline & 34 & $40 \mathrm{NS}$ & $9.5 \mathrm{NS}$ & 0.1 \\
\hline & 35 & $34.5 \mathrm{NS}$ & $1^{* *}$ & 35.5 \\
\hline & 36 & $51.5 \mathrm{NS}$ & $3^{* *}$ & 2 \\
\hline \multirow[t]{5}{*}{$\mathrm{E}$} & 7 & $8.5 \mathrm{NS}$ & $11 \mathrm{NS}$ & 17 \\
\hline & 10 & 18 NS & $35 \mathrm{NS}$ & 20.5 \\
\hline & 14 & $10 \mathrm{NS}$ & 19.5 NS & 36.5 \\
\hline & 19 & $14.5 \mathrm{NS}$ & $2.5^{* *}$ & 55.5 \\
\hline & 22 & 19 NS & 6 NS & 45 \\
\hline
\end{tabular}

4.4. Land use becomes a major driver of vegetation from 4500 to $4000 \mathrm{BP}$

The second phase of land-use effects on vegetation is recorded from 4500 to 4000 BP (2 in Fig. 8). At a sub-continental scale, this phase is characterised by the occurrence of arable land, an increase of open land and further decreases of broadleaved forest (Fig. 8). This spread of open land at the expense of broadleaved trees supports the most significant decrease in forest cover and broadleaved forest at 4000 BP observed by Fyfe et al. (2015). Davis et al. (2015) inferred the establishment of similar patterns in modern European vegetation from $4000 \mathrm{BP}$. Our results also indicate the gradual development of modern vegetation (decrease in SCD past-present) from $4000 \mathrm{BP}$ at a sub-continental scale. Although the cover of broadleaved forests has been substantially reduced by land use, Fagus and Carpinus might have been favoured by human activities during the late-Holocene (Ralska-Jasiewiczowa et al., 2003; Bradshaw and Lindbladh, 2005; Giesecke et al., 2007; Bradley et al., 2013). This assumption is supported at the local scale by earlier pollen studies (e.g. Björkman, 1999) which discuss factors other than climate that are crucial for the establishment of species (e.g. disturbance, seed dispersal, human activities). Nevertheless, our results indicate that Neolithic deforestation was the change that most affected tree composition in most of Europe from 4500 to 4000 BP. In particular, deforestation from 4000 BP caused a decreasing trend of RV evenness in regions B and C (slight) and in Region $\mathrm{E}$ (significant), and increasing trends in rate of change in regions $\mathrm{E}$ and $\mathrm{B}$, and from $3500 \mathrm{BP}$ in regions $\mathrm{A}$ and $\mathrm{C}$.

The human agency of these vegetation changes would seem to be confirmed by the still increasing influence of land use based on VP, as well as the increase of the combined effect of land use and climate. Furthermore, the land-use effect on $\mathrm{S}$ starts to increase from $4500 \mathrm{BP}$, and from ca. $3500 \mathrm{BP}$, land use has a higher significance than climate in the RDA (Fig. 9). Land use has the highest values as predictor of vegetation composition for the period 5500-2000 BP (Fig. 6) - all regions attain their maximum values in term of percentage of RV variation explained by land use (except Region E). At 3500 BP, land use provides a greater explanation of vegetation composition than climate in most of the regions (except Region D; Fig. 6). For regions B and C, VP further indicates the end of the regular increase of climate influence on vegetation at $5500 \mathrm{BP}$. Reitalu et al. (2013) found that land use becomes the strongest driver of forest compositional change from 4000 BP in Estonia. Our study shows that land use becomes a major controller of change, albeit less important to climate in terms of VP (at a sub-continental scale), although climate influence on vegetation still decreases strongly and gradually; at $4000 \mathrm{BP}$, climate accounts for $22 \%$ compared to $3 \%$ for land use.

\subsection{Combined effect of climate and land use on vegetation from 2000 to $1500 \mathrm{BP}$}

From 2000 to $1500 \mathrm{BP}$, a third phase begins of a land-use effect on vegetation composition ( 3 in Fig. 8). This is characterised by the widespread extension of arable land and the second greatest period of deforestation after that from 4000 BP. This causes a strong reduction of broadleaved and, to a lesser extent, coniferous forest, with the highest rate of vegetational change observed since 10,500 BP. These large increases in the cover of arable and open land for the last 2000 years over the entire study area corroborate the findings of Marquer et al. (2014), Davis et al. (2015), and Fyfe et al. (2015).

The major consequences of these rapid changes are a break in the decreasing trend in turnover and a further decrease in RV evenness at the sub-continental scale. The decrease in RV evenness over the last 1500 years in all regions, except $\mathrm{D}$, was not found in the earlier study by Marquer et al. (2014) which showed a relatively constant RV evenness through the late-Holocene. Matthias et al. (2015) also found a decrease in palynological evenness, and Reitalu et al. (2015) a slight decrease in pollen percentage-based and RV-based evenness, as well as a decrease in phylogenetic diversity after $2000 \mathrm{BP}$. This suggests that land-use changes over this period had more negative effects on pollen-based measures of evenness than during earlier periods.

Land use is a major factor of vegetation composition over the last 2000 years, as the $S$ indices show (Fig. 9). During this period, vegetation continued to become progressively more similar to that of today (decrease in SCD past-present) and thereby human influenced on vegetation is still increasing. This is not so evident if we consider the RDA results as these tend to indicate a larger climate than land-use influence (Figs. 6 and 9), while climate overtakes land use in significance from $1000 \mathrm{BP}$, except in Region E where land use rises and is higher than climate. Furthermore, the decreasing trend in climate-induced vegetation (see VP) is more regular from $2000 \mathrm{BP}$. It is also at this time that the combined effect of climate and land use on vegetation starts to be the major driver of vegetation composition at the sub-continental scale. Reitalu et al. 


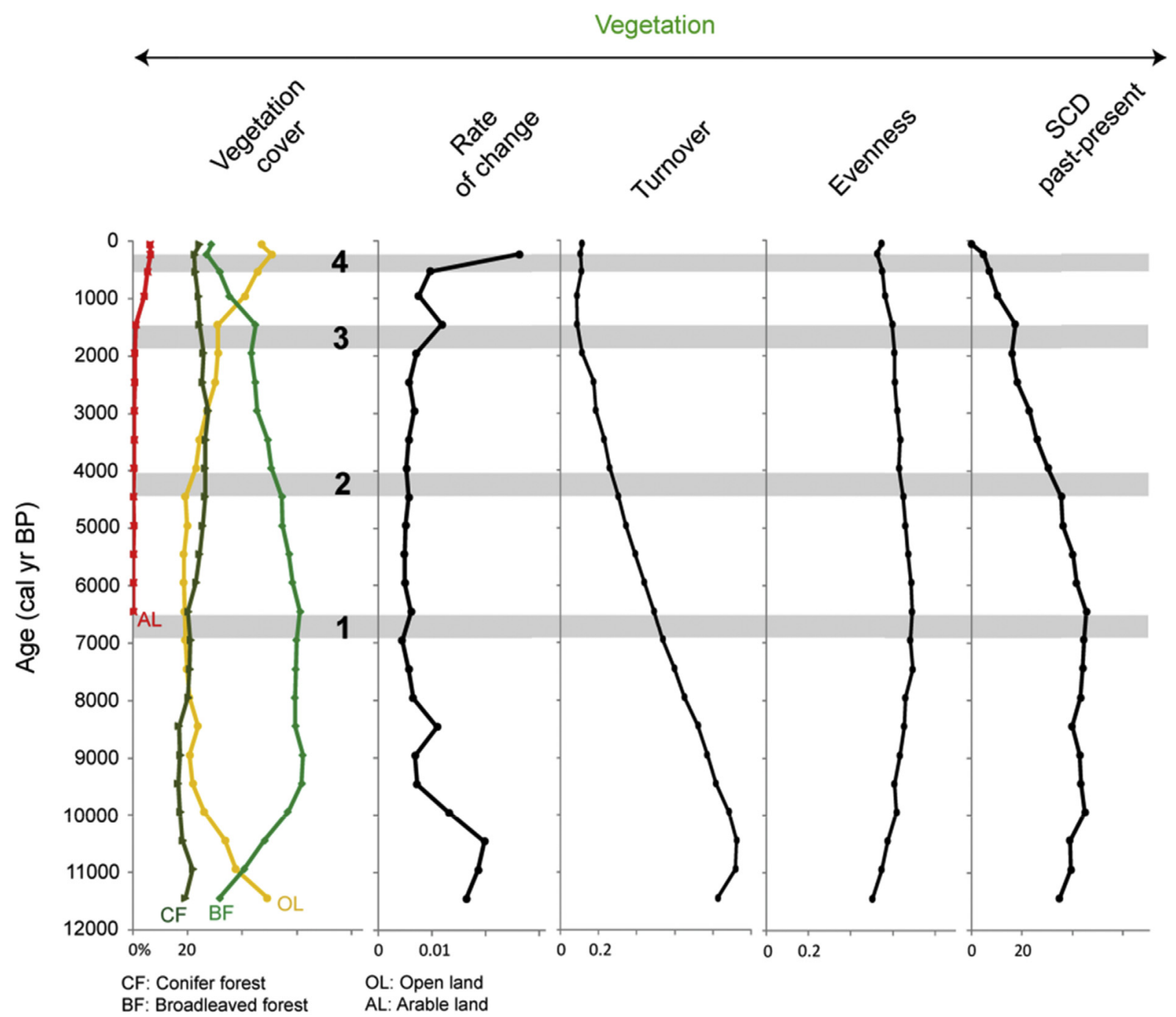

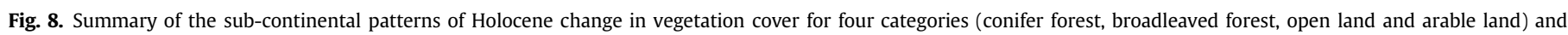

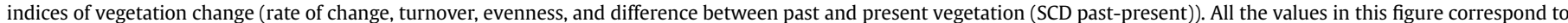

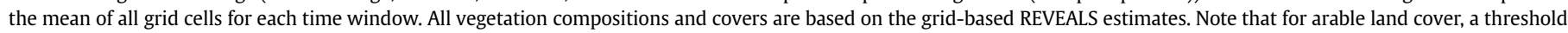

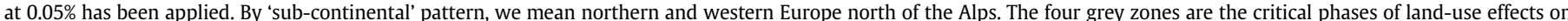

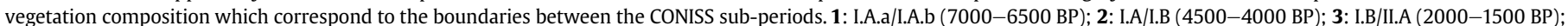
4: II.A/II.B (500-350 BP).

(2013) also found that both climate and land use have significant effects on forest compositional change during the late-Holocene in Estonia.

Fyfe et al. (2015) and Davis et al. (2015) argue that anthropogenic changes in land cover over the past 2000 years resulted in the establishment of the modern cultural landscape of Europe. This landscape saw a consolidation of settlement and land-use structures from the Late Iron Age (supported by archaeological and palaeoecological data) that has persisted with attendant cultural impacts for almost two millennia (e.g. Berglund, 1991; Gaillard et al., 2009). Our results suggest that humans had a major impact on vegetation composition over the last 2000 years, but that land use alone was not the most important driver of vegetation change (in terms of percentage of variation explained). Instead, land use and climate together governed vegetation change. There are various explanations for the finding of the continued role of climate on regional vegetation cover throughout the late-Holocene. For example, the expansion of Picea across Fennoscandia was most likely a consequence of the shift to a cooler climate and increased seasonality, which probably contributed to the decline of temperate broadleaved trees and retreat of the arctic tree line (e.g. Kullman, 2001; Giesecke and Bennett, 2004; Seppä et al., 2009). Land use might also have been partly controlled by climate - the decrease of RV variation explained by land use at $350 \mathrm{BP}$ occurred during the phase of Little Ice Age cooling. This climate event probably affected farming practices and crops, causing economic crises (e.g. Le Roy Ladurie, 2006; Dalgaard et al., 2015). The combined effect of climate and land use on vegetation demonstrates the existence of early feedback loops between climate, land use and vegetation and this becomes stronger over the last millennia towards the present.

Our results suggest that climate was the strongest driver of vegetation over the study area as a whole until $2000 \mathrm{BP}$, and climate together with land use prevailed after 2000 BP. Within Europe, for both regions $B$ and $C$, climate combined with land use was the major driver for a short period only (1000-500 BP). At 13.5 and $6.2 \%$, the respective effects of climate and land use are more similar at $2000 \mathrm{BP}$ than for previous periods (Fig. 9). 


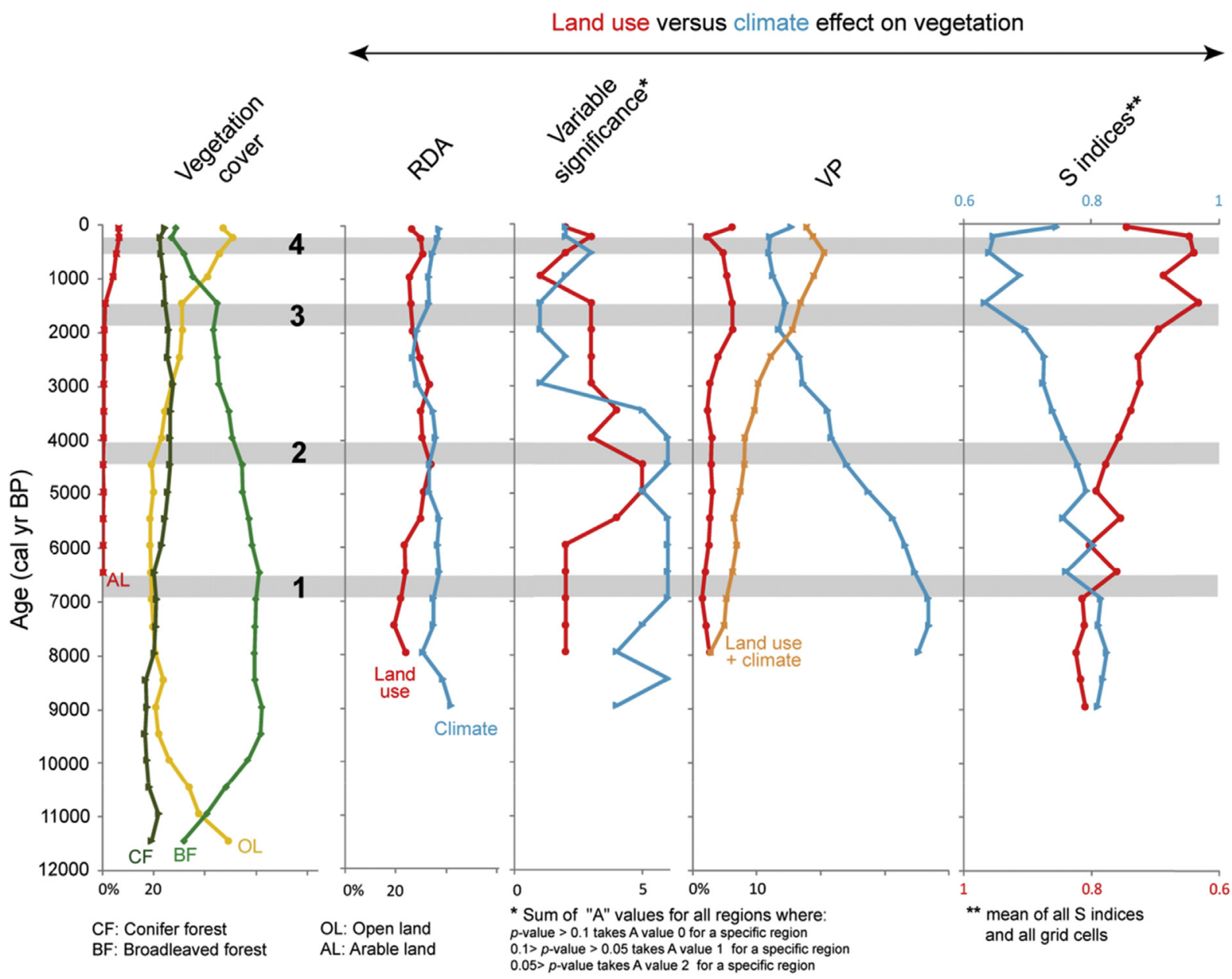

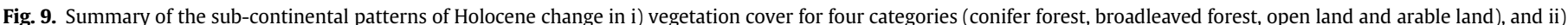

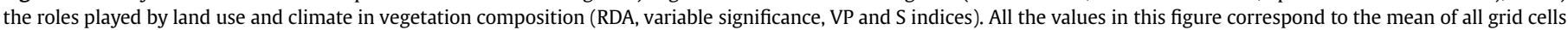

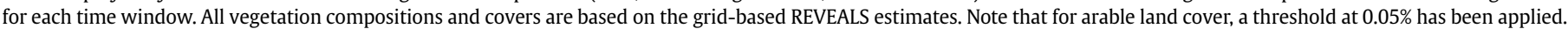

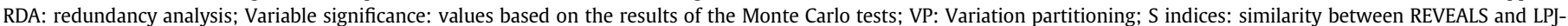

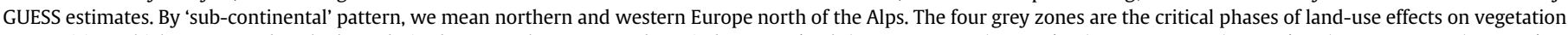

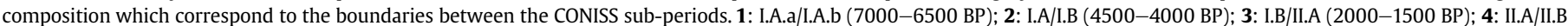
(500-350 BP).

\subsection{Acceleration of vegetation changes from 500 to $350 \mathrm{BP}$}

The last phase of a land-use effect on vegetation occurs from 500 to $350 \mathrm{BP}$ (4 in Fig. 7). Arable land continues to increase until the last few centuries, but at a decreasing rate. In contrast, coniferous and broadleaved forests expand again and open land is reduced over the last century. These changes in vegetation cover and composition are the fastest for the entire Holocene at the subcontinental scale. This marked acceleration in vegetation changes is also observed at regional scales (A, B and C). This results in increases in turnover and RV evenness that were otherwise decreasing over the last 10,500 and 6500 years, respectively. From 500 to $350 \mathrm{BP}$, vegetation becomes most similar to that of the present. Periods of rapid change are also documented over the last 1000 years by Finsinger et al. (2017) who attribute these modifications to the contribution from anthropogenic land-cover changes. The Industrial Revolution that began during the 18th century with a general expansion from the 19th century and the conflation with population growth and industrialization during the 20th century, had great influences on societies through the development of new techniques for agriculture. Land use has thus been intensively and extensively developed and its impact on vegetation might have been substantial over short time scales, resulting in rapid changes in vegetation composition. The mid-20th century is referred to as a period of great acceleration of population growth and industrialization (Ellis, 2011; Steffen et al., 2015; Waters et al., 2016). This may be a direct or indirect cause of our identified acceleration in vegetation changes during the last centuries.

Humans are therefore a major driver of vegetation composition over the last centuries. However, our results emphasise that while people have a major control over vegetation change, climate also exerts a strong influence. In the previous period ( 3 in Fig. 9), the combined effect of climate and land use on vegetation was the major driver, but for the last centuries, the effects have diverged; there is a decrease in the combined effect in VP and an increase in the individual influences of the two factors. Individual climate impact on vegetation is higher than the land-use influence at this time (see RDA in Fig. 9). S indices may further indicate an increase in the effect of climate (compared to land use) on vegetation over the last few centuries, possibly related to the Little Ice Age and subsequent warming, perhaps combined with the reduction in the area of arable land observed in most of the study region, and the resulting reforestation, with the species composition of the forests more dependent on climate. 
Humans, via intense (e.g. large scale deforestation and expansion of arable land) and rapid (the last centuries) impacts, have greatly modified the Holocene trends in all indicators of vegetation. These human-induced changes correspond to a unique signature over at least the last 11,700 years.

\section{Conclusions}

- The grid-based REVEALS estimates of plant abundance are useful for the analysis of regional to sub-continental-scale vegetation change, i.e. for northern and western Europe north of the Alps.

- The combination of pollen-based REVEALS estimates with climate, dynamic vegetation and anthropogenic deforestation modelling provides new insights into the relative impacts of land use and climate on Holocene vegetation.

- Climate is the major driver of vegetation composition for the Holocene as a whole, although a regional variability is observed and land use has been an important factor in northern Germany, Great Britain, Ireland, southern Sweden and Poland.

- Early effects of the beginning of farming and Neolithic forest clearances (reduction of broadleaved forest) on vegetation are recorded from 7000 to $6500 \mathrm{BP}$. The establishment of modern European vegetation patterns starts at that time. Climate is still the dominant controller of vegetation.

- Land use, in particular deforestation of broadleaved woodland, becomes a major driver of vegetation from 4500 to $4000 \mathrm{BP}$, although climate is still the major control. Climate influence is, however, decreasing.

- Climate is the strongest driver of vegetation until 2000 BP, and climate together with land use prevails after 2000 BP. From 2000 to $1500 \mathrm{BP}$, a rapid extension of farming and deforestation is recorded. The continued influence of climate on vegetation throughout the late-Holocene is most likely a consequence of shifts in late-Holocene climate. Farming practices and crops might also have been partly controlled by late-Holocene climate events.

- Acceleration of vegetation changes from 500 to 350 BP characterises a unique signature of anthropogenic impacts on landscapes. This is caused by agricultural modernization and afforestation to satisfy the demands of population growth and industrialization. Climate and land use have again become recognizable separate effects, and the influence of climate appears to increase, possibly related to the Little Ice Age and subsequent warming.

- This knowledge of land-use and climate impacts on vegetation underlines the importance of long-term trends in fully understanding natural- and human-induced variability in land cover. More attention to the time dimension could improve the formulation of sustainable adaptation strategies in nature conservation, as well as the improvement of dynamic vegetation models in order to obtain more reliable projections of future land-use and climate change impacts on ecosystems.

\section{Author contributions}

L.M., M.J.G., S.S., A.M.J. and B.S. conceived the initial idea; A.P. ran the LPJ-GUESS model and provided the simulated climate data; L.M., A.K.T., F.M., A.B.N. and R.M.F. ran the REVEALS model; J.O.K. provided the KK10 data; M.J.G., T.A., H.J.B., A.E.B., J.C., J.D., K.J.E., T.G., U.H., M.K., T.K., M.L., J.L. and H.S. provided the pollen data; L.M. led analyses and writing with substantial input from M.J.G. and S.S. All authors contributed to various versions of the manuscript.

\section{Acknowledgements}

This work is part of the LANDCLIM (LAND cover -CLIMate interactions in NW Europe during the Holocene) project (supported by the Swedish Research Council VR) and research network (supported by the Nordic Council of Ministers NordForsk) (2009-2011 and supported later by MERGE, see below) coordinated by M.J. Gaillard. It is also a contribution to the Strategic Research Area MERGE (ModElling the Regional and Global Earth system; http:// www.merge.lu.se), the Swedish Research Programme on Climate, Impacts and Adaptation (Mistra-SWECIA; http://www.mistraswecia.se/en), the Linnaeus Centre of Excellence LUCCI, the PAGES LandCover6k working group (http://www.pastglobalchanges.org/ ini/wg/landcover6k/intro) coordinated by M.J. Gaillard, and the Crafoord Foundation research project 'Long term impact of changes in climate and land use on forest tree species composition in south Sweden' coordinated by A.M. Jönsson and L. Marquer. J.O. Kaplan was supported by the European Research Council (COEVOLVE, 313797). We thank all members of the LANDCLIM network for data contributions and constructive discussions and the reviewers and the editor for helpful and insightful comments.

\section{Appendix A. Supplementary data}

Supplementary data related to this article can be found at http:// dx.doi.org/10.1016/j.quascirev.2017.07.001.

\section{References}

Behre, K.E., 1988. In: Huntley, B., Webb, T. (Eds.), The Role of Man in European Vegetation History. Vegetation History, pp. 633-672 (Dordrecht, Netherlands).

Berglund, B.E., 1991. The Cultural Landscape during 6000 Years in Southern Sweden. Ecological Bulletins 41, Copenhagen.

Berglund, B.E., Birks, H.J.B., Ralska-Jasiewiczowa, M., Wright, H.E., 1996. Palaeoecological Events during the Last 15,000 Years: Regional Synthesis of Palaeoecological Studies of Lakes and Mires in Europe. John Wiley \& Sons, Chichester.

Berglund, B.E., Gaillard, M.J., Björkman, L., Persson, T., 2008. Long-term changes in floristic diversity in southern Sweden: palynological richness, vegetation dynamics and land-use. Veg. Hist. Archaeobotany 17, 573-583.

Birks, H.J.B., Birks, H.H., 2008. Biological responses to rapid climate change at the Younger Dryas-Holocene transition at Kråkenes, western Norway. Holocene 18, 19-30.

Birks, H.J.B., Felde, V.A., Bjune, A.E., Grytnes, J.-A., Seppä, H., Giesecke, T., 2016. Does pollen-assemblage richness reflect floristic richness? A review of recent developments and future challenges. Rev. Palaeobot. Palynology 228, 1-25.

Björkman, L., 1999. The establishment of Fagus sylvatica at the stand-scale in southern Sweden. Holocene 9, 237-245.

Boyle, J.F., Gaillard, M.J., Kaplan, J.O., Dearing, J.A., 2011. Modelling prehistoric land use and carbon budgets: a critical review. Holocene 21, 715-722.

Bradley, L.R., Giesecke, T., Halsall, K., Bradshaw, R.H., 2013. Exploring the requirement for anthropogenic disturbance to assist the stand-scale expansion of Fagus sylvatica L. outside southern Scandinavia. Holocene 23, 579-586.

Bradshaw, R.H.W., Lindbladh, M., 2005. Regional spread and stand-scale establishment of Fagus sylvatica and Picea abies in Scandinavia. Ecology 86, 1679-1686.

Broström, A., Nielsen, A., Gaillard, M.J., Hjelle, K.L., Mazier, F., Binney, H., Bunting, J. Fyfe, R., Meltsov, V., Poska, A., Räsänen, S., Soepboer, W., von Stedingk, H., Suutari, H., Sugita, S., 2008. Pollen productivity estimates of key European plant taxa for quantitative reconstruction of past vegetation: a review. Veg. Hist. Archaeobotany 17, 461-478.

Dalgaard, C.J., Hansen, C.W., Kaarsen, N., 2015. Climate Shocks and (Very) Long-run Productivity. Discussion Papers. Department of Economics, University of Copenhagen, pp. 1-33.

Davis, B.A.S., Collins, P.M., Kaplan, J.O., 2015. The age and post-glacial development of the modern European vegetation: a plant functional approach based on pollen data. Veg. Hist. Archaeobotany 24, 303-317.

Ellis, E.C., 2011. Anthropogenic transformation of the terrestrial biosphere. Phil. Trans. R. Soc. A 369, 1010-1035.

Finsinger, W., Giesecke, T., Brewer, S., Leydet, M., 2017. Emergence patterns of novelty in European vegetation assemblages over the past 15000 years. Ecol. Lett. 20, 336-346.

Fyfe, R.M., Beaulieu, J.L., Binney, H., Bradshaw, R.H.W., Brewer, S., Flao, A. Finsinger, W., Gaillard, M.J., Giesecke, T., Gil-Romera, G., Grimm, E.C., Huntley, B. Kunes, P., Kuhl, N., Leydet, M., Lotter, A.F., Tarasov, P.E., Tonkov, S., 2009. The European Pollen Database: past efforts and current activities. Veg. Hist. Archaeobotany 18, 417-424. 
Fyfe, R.M., Twiddle, C., Sugita, S., et al., 2013. The Holocene vegetation cover of Britain and Ireland: overcoming problems of scale and discerning patterns of openness. Quat. Sci. Rev. 73, 132-148.

Fyfe, R.M., Woodbridge, J., Roberts, N., 2015. From forest to farmland: polleninferred land cover change across Europe using the pseudobiomization approach. Glob. Change Biol. 21, 1197-1212.

Gaillard, M.J., Sugita, S., Bunting, M.J., et al., 2008. The use of modelling and simulation approach in reconstructing past landscapes from fossil pollen data: a review and results from the POLLANDCAL network. Veg. Hist. Archaeobotany 17, 419-443.

Gaillard, M.J., Dutoit, T., Hjelle, K., Koff, T., O'Connell, M., 2009. European cultural landscapes - insights into origins and development. In: Krzywinski, K. O'Connell, M. (Eds.), Cultural Landscapes of Europe: Fields of Demeter. Aschenbeck Media, Bremen, Germany, pp. 35-44.

Gaillard, M.J., Sugita, S., Mazier, F., et al., 2010. Holocene land-cover reconstructions for studies on land cover-climate feedbacks. Clim. Past 6, 483-499.

Giesecke, T., Hickler, T., Kunkel, T., Sykes, M.T., Bradshaw, R.H.W., 2007. Towards an understanding of the Holocene distribution of Fagus sylvatica L. J. Biogeogr. 34 $118-131$.

Giesecke, T., Bennett, K.D., 2004. The Holocene spread of Picea abies (L.) Karst. in Fennoscandia and adjacent areas. J. Biogeogr. 31, 1523-1548.

Giesecke, T., Davis, B., Brewer, S., et al., 2014a. Towards mapping the late Quaternary vegetation change of Europe. Veg. Hist. Archaeobotany 23, 75-86.

Giesecke, T., Ammann, B., Brande, A., 2014b. Palynological richness and evenness: insights from the taxa accumulation curve. Veg. Hist. Archaeobotany 23 217-228.

Giesecke, T., Brewer, S., Finsinger, W., Leydet, M., Bradshaw, R.H.W., 2017. Patterns and dynamics of European vegetation change over the last 15,000 years. J. Biogeogr. 44, 1441-1456.

Grimm, E., 1987. CONISS: a FORTRAN 77 program for stratigraphically constrained cluster analysis by the method of incremental sum of squares. Comput. Geosci $13,13-35$.

Hargreaves, J.C., Annan, J.D., Ohgaito, R., Paul, A., Abe-Ouchi, A., 2013. Skill and reliability of climate model ensembles at the Last Glacial Maximum and midHolocene. Clim. Past 9, 811-823.

Harrison, S.P., Bartlein, P.J., Izumi, K., Li, G., Annan, J., Hargreaves, J., Braconnot, P. Kageyama, M., 2015. Evaluation of CMIP5 palaeo-simulations to improve climate projections. Nat. Clim. Change 5, 735-743.

Hickler, T., Vohland, K., Feehan, J., Miller, P.A., Smith, B., Costa, L., Giesecke, T. Fronzek, S., Carter, T.R., Cramer, W., Kühn, I., Sykes, M.T., 2012. Projecting the future distribution of European potential natural vegetation zones with a generalized, tree species-based dynamic vegetation model. Glob. Ecol. Biogeogr. 21, 50-63.

Huntley, B., Bartlein, P.J., Prentice, I.C., 1989. Climatic control of the distribution and abundance of beech (Fagus L) in Europe and North-America. J. Biogeogr. 16, $551-560$.

Jacobson, G.L., Grimm, E.C., 1986. A numerical analysis of Holocene forest and prairie vegetation in central Minnesota. Ecology 67, 958-966.

Jönsson, A.M., Lagergren, F., Smith, B., 2015. Forest management facing climate change - an ecosystem model analysis of adaptation strategies. Mitig. Adapt. Strat Glob. Change 20, 201-220.

Kaplan, J.O., Krumhardt, K.M., Zimmermann, N., 2009. The prehistoric and preindustrial deforestation of Europe. Quat. Sci. Rev. 28, 3016-3034.

Klein Goldewijk, K.K., Beusen, A., van Drecht, G., de Vos, M., 2011. The HYDE 3.1 spatially explicit database of human-induced global land-use change over the past 12,000 years. Glob. Ecol. Biogeogr. 20, 73-86.

Kullman, L., 2001. Immigration of Picea abies into north-central Sweden. New evi dence of regional expansion and tree-limit evolution. Nord. J. Bot. 21, 39-54.

Kuosmanen, N., Seppä, H., Alenius, T., Bradshaw, R.H.W., Clear, J.L., Filimonova, L. Heikkilä, M., Renssen, H., Tallavaara, M., Reitalu, T., 2016a. Importance of climate, forest fires and human population size in the Holocene boreal forest composition change in northern Europe. Boreas 45, 688-702.

Kuosmanen, N., Seppä, H., Reitalu, T., Alenius, T., Bradshaw, R.W.H., Clear, J.L., Filimonova, L., Kuznetsov, O., 2016b. Long-term forest composition and it drivers in taiga forest in NW Russia. Veg. Hist. Archaeobotany 25, 221-236.

Lechterbeck, J., Edinborough, K., Kerig, T., Fyfe, R., Roberts, N., Shennan, S., 2014. Is Neolithic land use correlated with demography? An evaluation of pollen derived land cover and radiocarbon-inferred demographic change from Central Europe. Holocene 24, 1297-1307.

Legendre, P., 2008. Studying beta diversity: ecological variation partitioning by multiple regression and canonical analysis. J. Plant Ecol. 1, 3-8.

Le Roy Ladurie, E., 2006. Histoire humaine et comparée du climat. Broché Publishing, France.

Magurran, A.E., 2004. Measuring Biological Diversity. Blackwell Publishing, Oxford.

Marquer, L., Gaillard, M.J., Sugita, S., et al., 2014. Holocene changes in vegetation composition in northern Europe: why quantitative pollen-based vegetation reconstructions matter. Quat. Sci. Rev. 90, 199-216.

Matthias, I., Sebastian, M., Semmler, S., Giesecke, T., 2015. Pollen diversity captures landscape structure and diversity. J. Ecol. 103, 880-890.

Mauri, A., Davis, B.A.S., Collins, P.M., Kaplan, J.O., 2014. The influence of atmospheric circulation on the mid-Holocene climate of Europe: a data-model comparison. Clim. Past 10, 1925-1938.

Mazier, F., Gaillard, M.J., Kuneš, P., Sugita, S., Trondman, A.K., Broström, A., 2012 Testing the effect of site selection and parameter setting on REVEALS-mode estimates of plant abundance using the Czech Quaternary Palynological
Database. Rev. Palaeobot. Palynology 187, 38-49.

Mikolajewicz, U., Gröger, M., Maier-Reimer, E., Schurgers, G., Vizcaıno, M. Winguth, A.M.E., 2007. Long-term effects of anthropogenic CO2 emissions simulated with a complex earth system model. Clim. Dyn. 28, 599-633.

Miller, P.A., Giesecke, T., Hickler, T., Bradshaw, R.H.W., Smith, B., Seppä, H., Valdes, P.J., Sykes, M.T., 2008. Exploring climatic and biotic controls on Holocene vegetation change in Fennoscandia. J. Ecol. 96, 247-259.

Mitchell, F.J.G., 2005. How open were European primeval forests? Hypothesis testing using palaeoecological data. J. Ecol. 93, 168-177.

Nielsen, A.B., Giesecke, T., Theuerkauf, M., et al., 2012. Quantitative reconstructions of changes in regional openness in north-central Europe reveal new insights into old questions. Quat. Sci. Rev. 47, 131-149.

Odgaard, B.V., 2007. Reconstructing past biodiversity. In: Elias, S.A. (Ed.), Encyclopedia of Quaternary Science. Elsevier, Amsterdam, pp. 2508-2514.

Pirzamanbein, B., Lindström, J., Poska, A., et al., 2014. Creating spatially continuous maps of past land cover from point estimates: a new statistical approach applied to pollen data. Ecol. Complex. 20, 127-141.

Prentice, I.C., Parsons, R.W., 1983. Maximum likelihood linear calibration of pollen spectra in terms of forest composition. Biometrics 39, 1051-1057.

Ralska-Jasiewiczowa, M., Nalepka, D., Goslar, T., 2003. Some problems of forest transformation at the transition to the oligocratic/Homo sapiens phase of the Holocene interglacial in northern lowlands of central Europe. Veg. Hist. Archaeobotany 12, 233-247.

Reitalu, T., Seppä, H., Sugita, S., Kangur, M., Koff, T., Avel, E., Kihno, K., Vassiljev, J., Renssen, H., Hammarlund, D., Heikkilä, M., Saarse, L., Poska, A., Veski, S., 2013. Long-term drivers of forest composition in a boreonemoral region: the relative importance of climate and human impact. J. Biogeogr. 40, 1524-1534.

Reitalu, T., Gerhold, P., Poska, A., Partel, M., Vali, V., Veski, S., 2015. Novel insights into post-glacial vegetation change: functional and phylogenetic diversity in pollen records. J. Veg. Sci. 26, 911-922.

Schurgers, G., Mikolajewicz, U., Gröger, M., Maier-Reimer, E., Vizcaıno, M., Winguth, A.M.E., 2006. Dynamics of the terrestrial biosphere, climate and atmospheric $\mathrm{CO} 2$ concentration during interglacials: a comparison between Eemian and Holocene. Clim. Past 2, 205-220.

Seppä, H., Alenius, T., Bradshaw, R.H.W., Giesecke, T., Heikkilä, M., Muukkonen, P., 2009. Invasion of Norway spruce (Picea abies) and the rise of the boreal ecosystem in Fennoscandia. J. Ecol. 97, 629-640.

Shennan, S., Downey, S.S., Timpson, A., Edinborough, K., Colledge, S., Kerig, T., Manning, K., Thomas, M.G., 2013. Regional population collapse followed initial agriculture booms in mid-Holocene Europe. Nat. Commun. 4 http://dx.doi.org/ $10.1038 /$ ncomms3486.

Šmilauer, P., Lepš, J., 2014. Multivariate Analysis of Ecological Data Using CANOCO 5. Cambridge University Press.

Smith, B., Prentice, I.C., Sykes, M.T., 2001. Representation of vegetation dynamics in the modelling of terrestrial ecosystems: comparing two contrasting approaches within European climate space. Glob. Ecol. Biogeogr. 10, 621-637.

Smith, D., Whitehouse, N.J., 2010. How fragmented was the British Holocene wildwood? Perspectives on the "Vera" grazing debate from the fossil beetle record'. Quat. Sci. Rev. 29, 539-553.

Steffen, W., Broadgate, W., Deutsch, L., Gaffney, O., Ludwig, C., 2015. The trajectory of the anthropocene: the great acceleration. Anthr. Rev. 2, 81-98.

Sugita, S., 1994. Pollen representation of vegetation in Quaternary sediments: theory and method in patchy vegetation. J. Ecol. 82, 881-897.

Sugita, S., 2007a. Theory of quantitative reconstruction of vegetation I: pollen from large sites REVEALS regional vegetation composition. Holocene 17, 229-241.

Sugita, S., 2007b. Theory of quantitative reconstruction of vegetation II: all you need is LOVE. Holocene 17, 243-257.

Trondman, A.K., Gaillard, M.J., Sugita, S., Fyfe, R., Kaplan, J., Nielsen, A.-B., Marquer, L., Mazier, F., Poska, A., Strandberg, G., 2012. Land cover-climate interactions in NW Europe, $6000 \mathrm{BP}$ and $200 \mathrm{BP}$ - first results of the Swedish LANDCLIM project. In: IPC/IOPC 2012, SS07-014, p. 530.

Trondman, A.K. Gaillard, M.J., Mazier, F., et al., 2015. First pollen-based quantitative reconstructions of Holocene regional vegetation cover (plant functional types and land-cover types) in Europe suitable for climate modelling. Glob. Change Biol. 21, 676-697.

Trondman, A.K., Gaillard, M.J., Sugita, S., Björkman, L., Greisman, A., Hultberg, T. Lagerås, P., Lindbladh, M., Mazier, F., 2016. Are pollen records from small sites appropriate for REVEALS model-based quantitative reconstructions of past regional vegetation? An empirical test in southern Sweden. Veg. Hist. Archaeobotany $25,131-151$.

Tutin, T.G., Heywood, V.H., Burgess, N.A., Moore, D.M., Valentine, D.H., Walters, S.M., Webb, D.A., 1964-1980. Flora Europaea. Cambridge University Press, Cambridge, UK.

Vellend, M., 2001. Do commonly used indices of $\beta$-diversity measure species turnover? J. Veg. Sci. 12, 545-552.

Vera, F.W.M., 2000. Grazing Ecology and Forest History. CAB International, Oxford.

Waters, C.N., Zalasiewicz, J., Summerhayes, C., et al., 2016. The Anthropocene is functionally and stratigraphically distinct from the Holocene. Science 351, 138-147.

Willis, K.J., Birks, H.J.B., 2006. What is natural? The need for a long-term perspective in biodiversity conservation. Science 314, 1261-1265.

Woodbridge, J., Fyfe, R.M., Roberts, N., Downey, S., Edinborough, K., Shennan, S., 2014. The impact of the Neolithic agricultural transition in Britain: a comparison of pollen-based land cover and archaeological 14C date-inferred population change. J. Archaeol. Sci. 51, 216-224. 